\title{
China Miéville: \\ The Work of Mourning
}

\author{
By Peter Owen
}

A thesis submitted to the Victoria University of Wellington in fulfilment of the requirements for the degree of Master of Arts in English Literature

Victoria University of Wellington

Te Whare Wānanga o te Ūpoko o te Ika a Māui

2018 


\section{Contents}

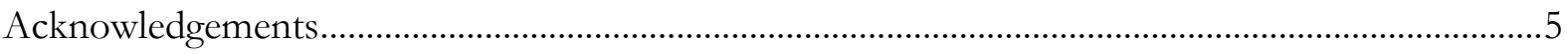

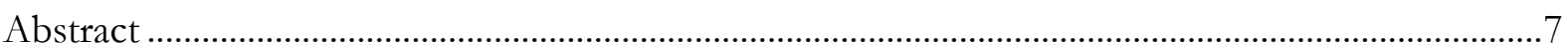

Introduction: Miéville, Post-Marxism, and Thinking Fantasy ..........................................................

Chapter One: Challenges to Cognition in The City \& The City............................................................. 21

Chapter Two: Romanticism after the Crisis: The Last Days of New Paris ........................................... 33

Chapter Three: Against the Individual Subject in This Census-Taker ............................................... 53

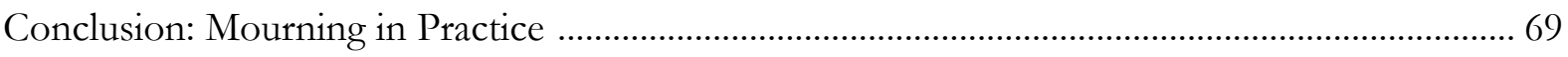

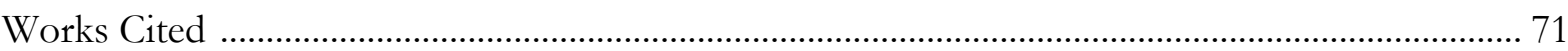




\section{Acknowledgements}

I am very grateful for the support of a Victoria University of Wellington Master's Scholarship, thank you.

Thank you also to everyone who has supported me throughout the year, especially Mum, Dad, Sally and Pip.

And thank you to Dougal McNeill for your fantastic (and fantastically patient) supervision. 


\begin{abstract}
This thesis begins from an attempt to place recent changes in science fiction and fantasy criticism in context within contemporary debates and schisms within Left politics. It examines the ways in which China Miéville's fiction reflects on and intervenes in these debates on questions of modernity, community, and collectivity. Through readings of The City \& the City, The Last Days of New Paris, and This Census-Taker, I seek to examine the ways in which Miéville's fiction, through an acknowledgement of the impossibility of escaping historically and culturally situated perspectives and through an awareness of the dangers of the appeal to community, arrives at the position of foregrounding contingency, heterogeneity, and ambiguity. Drawing particularly on Derrida's image of the ghost in Spectres of Marx and its exploration and elaboration in the work of Simon Critchley, I argue that Miéville's writing, especially in his most recent novellas, is representative of, and participative in, politics as a work of mourning.
\end{abstract}




\section{Introduction:}

\section{Miéville, Post-Marxism, and Thinking Fantasy}

This thesis takes as its subject a quartet of interrelated objects. These four objects, two concerning politics and two concerning fiction, are bound together in a kind of complex planetary dance. One might say that they each exert a binding and propelling force on the others, or, thinking more biologically, one might say that the four co-evolve. The first of these two objects of interest are political: the thinking of politics, its imagining and theorising, and the doing of politics. The second two concern fiction, and are similarly split: on the one hand, 'fictioning' itself, the doing of fiction, and on the other hand criticism, the thinking about fiction.

China Miéville sits neatly at the intersection of these four forces as a producer of both fiction and of criticism/theory of fiction, and as both a political theorist and a political actor. Miéville is a celebrated science fiction and fantasy author, both critically (having received, among others, three prestigious Arthur C. Clarke awards and a Hugo award for best novel) and in terms of popular appeal. He has an extensive fan following and has been the subject of a great deal of scholarly attention, including being the subject of a special edition of Extrapolation. This status as an acclaimed author and figure embedded in the field of literary thinking suggest that while Miéville is a singular figure, he may also be taken as symptomatic of and participant in broader intellectual movements and shifts.

His first novel, King Rat (1998), was an urban fantasy set in London in the late 1990's. It prefigures in many ways the rest of his work, being interested in the city as a space which generates resistant creativities, in hidden realities, and in revolution.

His next three novels, Perdido Street Station (2000), The Scar (2002) and Iron Council (2004), form a loosely connected trilogy, called the Bas-Lag trilogy after their shared setting. The three form a distinct phase in Miéville's work. They are dense, elaborate works of world-creation, and are often read as elaborate metaphorical encounters with life under late-capitalist post-modernity. Perdido Street Station follows two protagonists, the illicit lovers Lin (a bug-headed Khepri) and Isaac (a former professor of thaumaturgy turned rogue scientist). The central conflict of the novel begins when Isaac accidentally causes the release of a group of voracious and powerful monsters, slake moths, which threaten to destroy the city of New Crobuzon. In The Scar a ship 
travelling from New Crobuzon to the colony of Nova Esperium is captured by pirates, and its crew and cargo of slaves are press-ganged into citizenship of Armada, a floating pirate city. Armada's leaders, the Lovers, seek to travel to the Scar, a place in the world where reality breaks down and where, potentially, anything is possible. Iron Council returns in part to New Crobuzon. It follows three narrative threads, two in the present and one twenty years earlier. In the past, Judah Low works to extend a train line from New Crobuzon across Bas-Lag, and becomes involved in first a workers' strike and then their seizing of the train and line and formation of a mobile socialist collective, the eponymous Iron Council. In the present Cutter, a disciple and sometimes lover of Judah's after Judah's return to New Crobuzon to act as the Council's 'bard', follows Judah as he returns to the Iron Council to warn them of impending discovery by the New Crobuzon militia. Simultaneously, the revolutionary dissident Ori is involved in agitating and eventually rebellion. In the novel's climactic scenes the Iron Council return to New Crobuzon to aid the nascent collective, only to find them defeated. Fearing the Iron Council's destruction, Judah calls up a time golem and freezes the Council in time - a decision for which he is killed by his former lover and co-leader of the council Ann Hari.

After the trilogy, Miéville produced a series of stand-alone novels in various genres, beginning with Un Lun Dun (2007), a young adult urban fantasy novel set in London and its fantastical mirror image, UnLondon.

Miéville's next novel (with which this thesis will deal in greater detail) was The City \& the City (2009), a detective novel with a complicating science fiction twist. The story takes place in two overlapping cities, Besźel and Ul Qoma, the inhabitants of which are forbidden by law to interact with or even observe the other city. This law is enforced by the shadowy organisation 'Breach'. In this complicating setting Tyador Borlú, Besź policeman, uncovers a conspiracy while investigating the death of a foreign archaeology student.

Kraken (2010) returned to more fantastical pulp adventure and to a London with a magical underside. It follows Billy Harrow, an employee of the Natural History Museum who is drawn into a world of cults and magic after the theft of an embalmed giant squid.

Embassytown (2011), then, marks a shift towards 'hard' science fiction. It deals with the city of the title, Embassytown, on the planet Arieka. The novel deals primarily with the alien natives of that planet, referred to by the citizens of Embassytown as "Hosts", who have the strange quality of speaking a language in which signifier and signified are identical, making lying impossible. Host society suffers a catastrophic breakdown as the result of a partial erosion of this quality of language, and this eventually leads to the 'invention' of lying via the use of metaphor in order to save it. 
Continuing with the theme of entirely invented worlds, Railsea (2012) depicts a world in which the sea is made up of railway tracks. The railsea is 'sailed' by trains, some of which hunt giant moles. The novel begins by riffing on the well-known generic conventions of novels like Moby Dick but quickly spirals into more original territory.

2016 saw the publication of two novellas, and it is these novellas which, along with The City \& the City, are investigated here. The first, The Last Days of New Paris, depicts surrealist art coming alive in a Paris occupied by both Nazis and the forces of Hell. This Census-Taker is a strange, cryptic text, telling the story of a boy's life in an impoverished fantasy world, and events which follow his mother's disappearance and possible murder by his father.

Finally, October: The Story of the Russian Revolution (2017) represents a shift from fiction towards (exhaustively researched and non-fictional) narrative history. On the Russian Revolution's centenary, it traces the October revolution and its aftermath.

In other non-fictional work, Miéville has established himself as a key figure in the theorising of genre fiction. His notable work in that context includes the vitally important "Cognition as Ideology: A Dialectic of SF Theory", the afterword to Red Planets: Marxism and Science Fiction (2009), a collection he edited with Mark Bould, along with the introduction to an edition of Historical Materialism focused on Marxism and fantasy.

Alongside his literary career, Miéville is a committed political thinker and organiser. His doctoral thesis, Between Equal Rights: A Marxist Theory of International Law, was published as a book in 2005. He stood for the House of Commons as a candidate for the Socialist Alliance in 2001, and until 2013 was a member of the UK Socialist Workers Party. Later in 2013 he became involved in the founding of Left Unity.

2015 saw the launch of Salvage, a self-described "quarterly of revolutionary arts and letters", "written by and for the desolated Left, by and for those committed to radical change" (Salvage, 'About'), a project of which Miéville was a founder and holds the roles of both commissioning editor and art \& fiction editor.

Miéville's work thus justifies his centrality for this investigation of (particularly) Leftist political/philosophical questions via an investigation of their interconnection with aesthetics. Why, though, the project itself? Why think politics at all?

What gives the thinking of politics its urgency and its charge in particular is its placement in time. The present is characterised by a pair of crises, the one on the back of the other, and it is this overlapping which rends it apart. The first of these crises motivated the set of complications and questionings which are often grouped together under the label of 'post-Marxism'. Tormey and Townshend describe this "diffuse pattern of interlocking and interrelated thoughts" (11) as a 
response to the events of 1968, which represented "the beginning of the 'end' of both Eastern and Western Marxism" in the "vanquishing of the notion that the Soviet Union represented the locus of anti-capitalist initiatives and a model for the 'toiling masses' around the world" (2). In their words, 1968 showed “that progressive politics was 'elsewhere' than in Marxist parties" (3) - a recognition that, they argue, was finally cemented in 1989. In the appropriately named Left Melancholy (2016), Enzo Traverso describes 1989 as a moment in which the Left became "spiritually roofless", forced to "recognise the failure of all the past attempts to transform the world". Further, he argues, "the ideas themselves with which we had tried to interpret the world were put into question", and every Left movement since has to "redefine their own intellectual and political identities" (xiv). Post-Marxism, then, emerges as "attempts to rescue aspects of Marxist thought from the collapse of Marxism as a global and political force in the later twentieth century and reorient them to take on new meaning within a rapidly changing cultural climate" (Tormey and Townshend 1). In an attempt at a rough taxonomy of the post-Marxist constellation, Tormey and Townshend identify six "core Marxist concepts" (5) which are problematised by Post-Marxism: Marx's theory of history, account of the revolutionary subject, account of ethics and positivist epistemology, the problem of vanguardism (both intellectual and material), and the problem of democracy (5-6). While this is both a partial and a very general list, it illustrates the scale of the problem. Chamsy el-Ojeili notes that these areas of questioning could be loosely divided between "questions of mapping and understanding the social" and questions of "utopian reference" (263) - that is to say, between questions around what is and what should/could/ought to be. Could anyone say that these questions have been answered since? Perhaps the only reasonable claim might be to say that Marx's 'determinate' theory of history has (supposedly) been discredited, such that the terrain of contention is now whether Marx's theory of history was ever determinate in the first place ${ }^{1}$ — but this is a 'conclusion' which tends to open up new spaces and problems rather than close them. In fact, it is this disavowing of a teleological account of history which brings the question of utopia to the fore. As for the rest of the questions Tormey and Townshend suggest, for the most part that terrain remains entirely open.

The second crisis, the crisis of 2007, then, a crisis of the capitalist world-system and (perhaps) an opportunity for a resurgent Left politics, brings these questions back into stark relief. It poses a problem for which the solution is no longer known, and so, as the world seems to careen into danger, there is no clear alternative. Zygmunt Bauman describes the situation with horrifying perspicacity:

\footnotetext{
${ }^{1}$ For one among many possible examples, see Löwy's "Marx's Dialectic of Progress: Closed or Open?"
} 
There is no promising invention in sight in which one could reinvest the hope of carrying all the rudderless victims out of trouble. After the loss of public trust in the wisdom and potency of the state, now it is the turn of the dexterity of the 'invisible hand of the market' to lose credibility. Every one of the old ways of doing things lies discredited, and the new ways are - at best - at the drawing board or experimentation stage. No one can swear, hand on heart, to the effectiveness of any. All too well aware of the hopes that failed, we have no runners-up to bet on. Crisis is a time for deciding what way of proceeding to take, but in the arsenal of human experiences there seem no trustworthy strategies to pick from (10-11).

As the editors of Salvage put it in "Salvage Perspectives \#1: Amid This Stony Rubbish" in the journal's first issue in late 2015, this is "not midnight of the century. But it is a long dusk. We require, in this half-light, a crepuscular Marxism”. While Salvage implies that their search for a "strategy for ruination" is strategic, that is, concerned with how already given goals might be achieved, the post-Marxist milieu in which they are writing (as el- Ojeili's observation of both descriptive and utopian questioning suggests) may require far deeper rethinking — not only of how goals might be achieved, but the very grounds upon which strategies are considered, not to mention the goals themselves. Salvage gets at this point when they declare "not of course that there is but one 'Left", that "Salvage addresses all, of all traditions, sincerely committed to radical change", and goes on to list "socialism; left anarchism; Marxism in its various flavours; and others." The disagreements between these groups are not merely tactical — though they often are. They are in some cases fundamentally different visions of what "radical change" might be in aid of, and, importantly, different visions of vision - of what el-Oijeli calls "questions of mapping". They also rest on radically different normative foundations. The depth of Salvage's searching, here, is strangely unmoored from any conception of what the Left might be apart from 'anti-capitalist'. What is needed, it seems, is a reimagining with a degree of depth that goes well beyond questions of organisation. What the present demands is an exploration to the very bottom of the Left project - to the heart of what a politics should be.

Given the weight (or perhaps the melodrama) of the question, fiction might seem a strange place to direct our attention. On the other hand, el-Oijeli's division of the problem-space into problems of perception and problems of utopia is a suggestive one, and links the foundational issues at hand to what seem to be literary questions: questions about imagining the future, and about ways of seeing, representing, and encountering the world. Bearing this connection out, an examination of the ways in which critical thinking about science fiction and fantasy have developed reveals a pair of competing, though overlapping, paradigms - 
paradigms which bear a uncanny resemblance to the political/philosophical areas of questioning which have already been discussed.

Leftist science fiction theory as such was inaugurated, and provided with its initial impelling energy, by Darko Suvin. In his Metamorphoses of Science Fiction (1979), Suvin made a claim for the political efficacy of the genre. He did so by drawing on Lukács's account of historical realism and claiming that while the 'areality' — that is, the current impossibility — of science fiction means that the knowledge gained through the text is not knowledge of the 'zero-world', the structure of the genre means that it provides 'cognitive' knowledge. Science fiction, in his view, uses "imagination as a means of understanding the tendencies latent in reality" (20). In practise, what this means is that for Suvin while there may be impossible or fantastical elements in a given work of science fiction, it will nonetheless share enough scientific laws with the zeroworld to shed light on that world's 'latent tendencies' (Suvin 20). In contrast fantasy is "a genre committed to the interposition of anti-cognitive laws into the empirical environment", and Suvin consigns it to the fate of being "a subliterature of mystification" (21).

Suvin's fundamental claim has had a remarkable persistence. As recently as 2005 , for example, as august a figure as Fredric Jameson was confident in taking Suvin's definition of the genre as 'a motto' (Jameson Archaeologies 414), and in referring to fantasy as "technically reactionary" (60). A variety of other thinkers have also updated and modified Suvin's framework. One such is Carl Freedman, in his Critical Theory and Science Fiction (2000). Freedman suggests a "cognition effect" rather than cognition proper: not any "epistemological judgement external to the text itself on the rationality or irrationality of the latter's imaginings, but rather...the attitude of the text itself to the kind of estrangements being performed" (18, emphasis in original). Freedman goes on to argue that "the readiest means of producing a cognition effect is precisely through cognition itself' (18). Freedman's cognition effect, despite jettisoning some of the more problematic elements of Suvin's position, still rests on the same fundamental assumptions regarding measurability and our attitude towards knowledge.

In a parallel argument, Seo-Young Chu inverts Suvin's original claim. Rather than arguing that science fiction is non-mimetic and thus estranging, Chu instead argues that science fiction should be considered "a mimetic discourse whose objects of representation are nonimaginary yet cognitively estranging" (3). These "cognitively estranging referents encompass the sublime (e.g., outer space), virtual entities (cyberspace), realities imperceptible to the human brain (the fourth dimension), phenomena whose historical contexts have not yet been fully realized (robot rights), and events so overwhelming that they escape immediate experience (shell shock)" (7). The set of objects Chu chooses, here, suggests a continuity with Suvin's claim rather than a disjunction. 
Suvin's distinction between SF and fantasy rests on the shared "latent tendencies" between fictional and 'real' world. His disregarding of fantasy likewise rests on the 'interposition of anticognitive laws'; so what this means in practise is that there exist certain 'objects' (if we take the expansive definition of object which allows for Chu's treatment of 'rights' or 'cyberspace' as objects) which Suvin sees it as science fiction's task to represent: objects like, for example, 'gravity'. If science fiction is to take its reader out of the world only to return them with new knowledge, then there must be knowledge of the world which was previously unknown but which is represented in the fiction. In essence, then, Suvin's theory is of science fiction as a mimetic genre.

A concern with uncovering hidden aspects of the 'zero-world' of the author and reader's reality runs throughout Freedman's Art and Idea in the Novels of China Miéville (2015). Freedman pursues productive readings of King Rat, Perdido Street Station, The Scar, Iron Council, The City \& the City, and Embassytown, and includes an extended meditation in his concluding chapter on the relationship between art and idea which serves as an updating of his claims in Science Fiction and Critical Theory.

These basic claims about the relation between politics and aesthetics and the claim that fiction should reflect and illuminate the world itself also tend to persist into attempts to rehabilitate fantasy. Freedman, for example, attempts to draw a line in "A Note on Marxism and Fantasy" between the "unhistorical" mode of fantasy and the "ahistorical" (266). He pursues this by way of a comparison between Tolkien's The Lord of the Rings (1945-1955) and Delany's Nevèrÿon tetralogy (1979-1987). Freedman concludes that, despite Delany's resolute unhistoricism, "the chief concerns of the four volumes are precisely those decisive for history and for historical materialism" (265-6). Freedman goes on to describe a variety of ways in which Delany's fiction illustrates various truths in Freedman's own empirical world. The novels reveal, for example, "how even mere children's toys can be consequentially commodified" (267) and the ways that capitalism might "powerfully remake" social structure, transforming in this case "what had been a rough gender egalitarianism into a full-fledged patriarchy" (267). Similarly, Jameson's vision of radical fantasy is as "a materialist fantasy, a fantasy narrative apparatus capable of registering systemic change and of relating superstructural symptoms to infrastructural shifts and modifications" (Radical Fantasy 280).

The Suvinian tendency in academic encounters with science fiction also runs through work on Miéville. Freedman's Art and Idea in the Novels of China Miéville, for example, deals with six novels, from King Rat to Embassytown. Part of Freedman's project takes the form of an attempt to defend Miéville's fantasy work against what appears to be the "damning indictment" 
(80) of "unrigorous and wishful thinking" (79). In a particularly telling passage on Iron Council, he does so by suggesting that the "supernatural elements" of the novel "can be understood as metaphorical displacements, within the invented world of Bas-Lag, of phenomena familiar enough in actual earthly history" - the importance of terrain, the need for unexpected allies, material technologies and so on (80). While Freedman notes the "unavailability of socialist revolution in the immediate empirical world" for representation, he still seeks to rehabilitate Miéville's fantasy fiction through the claim that it represents "reality nonetheless" (81). This realist or pseudo-realist reading practice runs throughout the text, and is not limited to fantasy. In reading The City \& the City, for example, Freedman argues that the novel reveals the ultimate deflationary force in our world: the "Yankee dollar" (103). He also argues that "the basic didactic viewpoint of Miéville's novel is a Marxist universalism according to which nationalism represents a regressive fetishization of intrinsically empty and imaginary differences" (140), another reading in which the nominally arealistic science fiction text is taken to provide real knowledge of the world of empirical reality. A given science fiction or fantasy text, Freedman argues, is successful on the basis of "taking us out of history...only to lead us back in again" (154). While Freedman's work is thorough and often perceptive, I find it unsatisfying (and it is this dissatisfaction which in some ways motivates this project). My sense is that Freedman goes to Miéville's fiction and finds in it a confident articulation of his (Freedman's) politics. He notes the many ways in which Miéville provides evidence for the need for that politics - through its revelation of the many injustices of the world we live in - and concludes that it is didactically effective. It seems to me that now is not the time for this kind of confirmation. Freedman is right to observe the crisis of the present, but is in my view under-attentive to the past crisis - the crisis of the Left. Furthermore, Freedman's view of the fantastical as metaphorically or allegorically representative of the non-fantastical world seems to domesticate it in a way which is under-attentive to the specific aesthetic pleasures and challenges of the impossible.

The materialist tendency which seeks to uncover real information about the world we live in through the examination of fiction is mirrored by a tendency which seeks instead to destabilise our knowledge of the world and of our beliefs. Following Suvin, we might label the former 'cognitive' and the latter 'estranging'. While this is by no means (as the original Suvinian combination of the two terms suggests) an exclusive relation, the distinction in attitude is sharp enough to consider these two tendencies as competing strains of the $\mathrm{SF} /$ fantasy critical virus.

In 2009, Miéville made his own critical intervention in the field with the afterword to the collection Red Planets: Marxism and Science Fiction, "Cognition as Ideology: A Dialectic of SF Theory". There, Miéville interrogates the Suvinian distinction between science fiction and fantasy 
and its updating in Freedman's cognition effect. He begins with the observation that "much of the supposed science in SF is precisely that - supposed" (233), and notes that since "cognition and the cognition effect are sometimes radically discontinuous" (237) that the cognition effect cannot be derived from "cognitive logic" (237). Therefore, he suggests, "the cognition effect is a persuasion" (238, emphasis in original). The question, then, becomes "whose cognition effect? More pertinently, whose cognition? And whose effect?” (235, emphasis in original). This leads Miéville to a startling conclusion: if the "experienced effect is in fact a function of authority, the 'cognition effect', in deriving supposed cognitive logic from external authority, is not only fundamentally a-rational but also intensely ideological." It therefore "surrenders the terrain of supposed conceptual logic and rigour to the whims and diktats of a cadre of 'expert' authorfunctions" (239). "To the extent that SF claims to be based on 'science' and indeed on what is deemed 'rationality", then, "it is based on capitalist modernity's ideologically projected selfjustification: not some abstract/ideal science, but capitalist science's bullshit about itself' (240). Rather than focusing on cognition, Miéville suggests that alterity be thought of as the central category for analysis - that "the atom of SF's and fantasy's estrangement, in other words, is their unreality function" (244).

Miéville's intervention had, unsurprisingly, a striking effect on scholarship relating to his work as an author. Sherryl Vint, for example, describes Miéville's fiction in "Ab-realism: Fractal Language and Social Change" as calling into question our very ability to access the world of reality (41). Instead, she argues, the fiction is "a way of making an argument about metaphor as a rigorous way of thinking", which "makes an argument about more fully seeing our social world beyond its ideological construction in mimetic realism". Rather than "making concrete and hence understandable what exceeds narrative realism", Miéville generates fiction which is "evasive", which "hates to be parsed" (43). This 'ab-realism' "multiplies our understanding of realism fractally, to include possibilities not dependent for their shape on their particular relation to the world described by realism" (44). Vint's focus here is not on the fiction as revelatory of any given injustice in the present world. Rather, the focus is strictly estranging: interested in the ability to think possibility in a non-determinate fashion. This tendency towards interpretative multiplication runs throughout the collection in which Vint's chapter appears: see, for example, Dougal McNeill's claim for "imagination, rather than cognition" as the 'keyword' for a political interpretation of Iron Council (108), or Paul March-Russell stressing "plentitude of meaning” in The City \& the City.

Sandy Rankin forcefully embodies this position in her "AGASH AGASP AGAPE: The Weaver as Immanent Utopian Impulse". There, she argues that Miéville "cognitively and 
emotionally imagines an immanent utopian impulse found in the latent and anticipatoryexpectant intoxication of our species-being" (256). Polemically, she argues that this distinguishes him from "well-trained Marxist cultural archaeologists" who "argue fetishistically as if cognition is all that matters" (256). These are clearly not only distinct but in some ways antagonistic tendencies. 
The hope is this. By examining the ways in which Miéville's fiction represents a working through and demonstration of both of the critical tendencies in science fiction/fantasy theory and the ways in which it more directly encounters political questions, some light might be cast (and reflected, and recast, and so on) on the parallel questions raised by the post-Marxists. The interrelatedness of the four objects with which we began (politics/fiction: thinking/doing) might mean that recognising the movement of the one tells us something about the movements of the others, and that the thinking of one object, the thinking of fiction, might in some way be the thinking of the others. Investigating literary questions concerned with the relationship between the thinking of and the doing of fiction might allow for a grip on questions of politics which their direct exploration does not - might allow a descent into the deep gravity well of the current crisis in search of some glimmers of new possibility, or, at the least, might reveal previously unseen weaknesses in the Left's existing foundations.

This is particularly the case when considering epistemological problems, such as the suspicion of positivism which Tormey and Townshend identify with post-Marxist thought (6), since fiction is necessarily a kind of record of experience, and is necessarily an attempt to bridge an epistemological, intersubjective gap. With that in mind, the thesis begins with Miéville's The City \& the City (2009), a novel which I argue represents a working-through of precisely the questions raised by the split in critical tendencies relating to science fiction. It functions as a kind of partner piece to Miéville's "Cognition as Ideology", interrogating the desire to reach an unmediated, a-cultural understanding of the real. The novel raises questions around epistemology and especially the possibility of intellectual expertise which draw Miéville into the larger field of questions associated with post-Marxism and the question of modernity. One of these questions which will be increasingly important in the consideration of later work is the question of whether the problems associated with the position of the intellectual expert deny us a vantage-point from which to imagine the future - a fundamental issue for the field of politics as concerned with how to change the course of the present.

In response, perhaps, to this question, The Last Days of New Paris takes as its object the opposite view: the question of whether a concern for the past might allow us to imagine a better future world. I read this novella against the background of the rise of populism and argue that while the novella does make a clear case for a Romanticist Left, it is ultimately more riven by worry than clearly programmatic, concerned as much with the reactionary risks of the appeal to community as with its potentials. I suggest that the novel aims to resolve this tension by linking the Romantic suspicion of reductive or subsumptive logic to a suspicion of reductive, subsuming social structures, a conclusion which poses a striking challenge for Left political organising. 
This Census-Taker, then, engages with this challenge. Continuing the criticism of reductive rationality which runs through The Last Days of New Paris, This Census-Taker works to connect that logic to the operation of the state through the mechanism of the census. Reading the novella against the conflict between two visions of the Left exemplified by Jeremy Gilbert and Jodi Dean, concerned with horizontalism and the party respectively, I suggest that the novella pursues a deconstruction of the individual form and thus avoids the problems of authority associated with Dean's pro-party position.

Finally, by way of a conclusion, I examine the metatextual elements of the two 2016 novellas, consider the ways in which the kinds of reading they imply might affect critical practice when it comes to Miéville's work, and suggest a way in which they might shape a future emancipatory politics. 


\section{Chapter One}

\section{Challenges to Cognition in The City \& the City}

The City \& the City, published in the same year as "Cognition as Ideology" seems to serve as an exploration of the space between the instrumental and the rational and as an exploration of the implications, successes, and failures of cognition. Ultimately, I will argue, this exploration is best read as a criticism of instrumental cognition. While Miéville frames a similar criticism in 'Cognition as Ideology' in explicitly (and unsurprisingly) anti-capitalist terms (calling the cognition espoused in much science fiction "capitalist modernity's ideologically projected selfjustification" (240), for example), his evocation of "a cadre of 'expert' author functions" (239) could presumably also be extended into a criticism of both centrally planned economic structures and the notion of a privileged revolutionary vanguard. The shift between Suvin and Miéville's viewpoints thus reflects shifts in the political-philosophical terrain between 1978 and 2009 as much as it does Miéville's more rigorous interrogation of the science fiction form. The interrogation of rationality performed in The City \& the City, then, is as illuminating for a reflexive exploration of the Left as it is for a condemnation of capitalism.

The novel begins with Inspector Tyador Borlú encountering the murdered corpse of (he will later learn) Mahalia Geary. In the first part of the novel, Borlú and his subordinate/partner Lizbyet Corwi work to unravel Mahalia's identity and hope to eventually solve the mystery of her death. Their investigation is complicated by the novel's arealistic setting. Borlú is a resident of Besźel, a fictional nation which partially overlaps with its 'neighbour' Ul Qoma. Those who are legally present in Besź are prohibited from sensing or interacting with their neighbours in Ul Qoma and vice versa, a prohibition which is enforced by the shadowy organisation 'Breach'. Borlú discovers that Mahalia's body was transported in a van owned by a man named Khurusch, but the separation of the two cities eventually frustrates his investigation, so that in part two of the novel he is forced to travel to Ul Qoma and to work with his counterpart there Quassim Dhatt. The two investigate Mahalia's place of work, the archaeological dig Bol Yan, and encounter 'outcast' academic David Bowden, author of a book on the mythical 'third city' of Orciny. This section of the novel culminates in Borlú's attempt to sneak Yolanda Rodriguez, one of Mahalia's classmates, and Bowden out of Ul Qoma, an attempt which ends in Rodriguez' 
death at the hands of an assassin. At the very end of part two, Borlú shoots the assassin across the boundary between the two cities and falls into the hand of Breach. In part three, Borlú participates in Breach's investigations from within, acquiring a new partner in the form of Ashil. In the final sequences of the text, Borlú discovers the conspiracy behind Mahalia's murder (a straightforwardly profit motivated scheme by international corporation Sear and Core), but is forced to let the company's representative in Besźel escape. In the aftermath of this encounter, Borlú realises that only David Bowden could have orchestrated the deception which tricked Mahalia into participating in Sear and Core's crime. He pursues Bowden and persuades him that he needs to be arrested by Breach rather than escaping to the outside world and dissatisfaction.

The City \& the City opens with a scene which seems purpose-built to establish its generic position. The novel begins with a crime scene in what is apparently a working-class housing estate. Weedy grass, "threaded with paths footwalked between rubbish, rutted by wheel tracks" and "police at various tasks" enclose a space "between a low derelict tower and a skateboard park surrounded by big drum shaped trash bins" (3). It is evidently early morning.

Compare to an early scene from popular Scottish crime novelist Ian Rankin's second novel, Hide and Seek:

The housing estate, what he could see of it through the rain-lashed windscreen, was slowly turning back into the wilderness that had existed here before the builders had moved in many years ago. He has no doubt that in the 1960s it, like its brethren clustered around Edinburgh, had seemed the perfect solution to future housing needs. And he wondered if the planners ever learned through anything other than hindsight. If not, then perhaps today's 'ideal' solutions were going to turn out the same way.

The landscaped areas comprised long grass and an abundance of weeds, while children's tarmacadamed playgrounds had become bombsites, shrapnel glass awaiting a tripped knee or stumbling hand. Most of the terraces boasted boarded-up windows, ruptured drainpipes pouring out teeming rainwater onto the ground, marshy front gardens with broken fences and missing gates. (1)

This immediate generic identification is especially important for the detective genre because it establishes the particular practises which will be required of the reader. As Peter Hühn notes in 'The Detective as Reader', detective fiction has been "remarkable for the rigidity of its conventional structures" (453). This is no accident. Perhaps more than any other, the detective story has always thought of itself as a game - and as a game, it has rules. To change the rules midway is to invalidate the game, and because the rules are never explicitly stated within the text 
itself, this constrains the text. John Frow describes a genre as a schema, "a pattern underlying a surface phenomenon which allows us to understand that phenomenon" (83). This 'schematic' function of genre is particularly important in the detective story, which is why it is so important that The City \& the City so decisively establish its genre within the opening page.

These generic assumptions and attendant reading practises are also established through the mode of narration. Borlú himself serves as homodiegetic narrator, using the first person and speaking for the most part in the past perfect tense. However, this has the feel of convention rather than conceit - Borlú never elaborates on his apparent position in the present of the text, and where his narrative discourse diverges from the temporal order of the story, it is always analeptic. He never, for example, names Mahalia Geary, until his narration reaches the point at which he discovered her name. The complete lack of interjection from his implied position in the future serves to maintain the 'puzzle' for his reader.

Borlú's narration, especially in the early scenes, is also largely devoid of judgement. While he occasionally uses the gnomic present ("Nothing is still like the dead are still" (3)), or notes an emotional reaction ("it was sad to see her skin smooth that cold morning" (4)), for the most part he notes only physical details in a quick and efficient tone which is reminiscent of (pop-culture representations of) a police report. For example, he describes the teenagers who found the body as "two girls, two guys. Midteens, cold, looking down" (5). This terseness also colours his dialogue within the opening scene. Borlú asks a series of quick questions of Corwi and the teenagers and receives longer and more elaborate answers. Borlú's diction here conceals his interiority — his judgement — from both those he questions and his reader. Despite the conceit that the novel is narrated by Borlú, presumably with an audience, Borlú does not allow access to his thought process. This neatly parallels the assumptions of the genre and the cognitive logic which underpins it. The neutrality of Borlú's observation and representation here suggests that there is a physical reality to the body, and that it can be read by a given 'reader' or observer in order to access this reality — so that, if the reader is paying the right kind of attention, they and Borlú will arrive at the same conclusions by way of the same evidence. Borlú is withholding judgement — that is, effacing his subjectivity — in order to not colour that implied reader's conclusions. Peter Hühn usefully describes these assumptions when he suggests that the detective genre is based on "the presupposition of a clear distinction between object and subject, between the (assumed) objectivity of the hidden meaning and the pure instrumentality of the detective's discerning intellect" (460). In this opening passage, Borlú's narration, uncoloured by subjective judgements and directed towards the physical reality of the scene and of the body, epitomises this purely instrumental, “discerning intellect". Further, because a reader recognises 
the markers of the genre and is embedded within Borlú's consciousness through focalisation, they are also invited to 'put on their detective hat' and assume the same 'rational' state of mind.

As if to underscore these assumptions and 'warm up' this cognitive practise, the passage which follows the examination of the crime scene involves Borlú staging a competition of sorts between Corwi and Naustin, two police officers. This competition begins when Borlú, as the senior detective on the scene, asks Naustin to give his interpretation of the crime-scene. Naustin, though careful to qualify his response as "first impressions" (9), replies that he believes the dead woman was probably a sex worker, a claim which he justifies in two ways. First, he gestures towards the area the body has been found, the "low derelict tower and a skateboard park ringed by big drum-shaped trash bins" (3). Second, he indicates her "exaggerated" makeup. From these two details, Naustin extrapolates into a fuller story. Mahalia, in this telling, is a "hooker" murdered by a "sicko" client (9).

Borlú then asks another police officer, Corwi, to comment on Naustin's interpretation. Corwi also notes Mahalia's makeup but unlike Naustin decides that its "earths and browns" colour scheme would be unusual for a sex worker in the area. Supporting this interpretation, Corwi notes that Mahalia's hair is not dyed, and is surprisingly clean. Based on these details, Corwi is unhappy with Naustin's account (10).

The 'competition' and the fact of Borlú having invited it have a variety of implications. Borlú has some sense that Naustin's interpretation is incomplete. His reaction makes this clear: after having heard Naustin's theory, he, unprompted, "raised an eyebrow" and "glanced in Naustin's direction" (10). These gestures, directed at Corwi, suggest an invitation for her to disagree. If Borlú were entirely confident in Naustin's interpretation, such an invitation would not be needed. Borlú had already made sure to let Corwi overhear Naustin, only asking for Naustin's interpretation once he is "positioned so that Corwi would be at the edge of our conversation" (9). The implication is that Borlú suspects that Naustin will misread the scene in fact, that Borlú already has a reading of the scene which he suspects Corwi will confirm but which Naustin will miss. Why, then, does he stage the disagreement between the two? One answer might be that this is an extension of Borlú's neutral, rational position, and that by hearing the less convincing version first Borlú hopes to avoid biasing his own interpretation in favour of Corwi's. He also avoids biasing either of the two younger police officers with his own interpretation. This process of subtracting the individual subjects from the interpretation reinforces the desire for objectivity. The fourth party in the conversation is the reader, who is likewise invited to formulate their own interpretation and to decide between Naustin and Corwi's before being given Borlú's own version of events. 
This implication of this scene is that, like Borlú, a reader will be able to adjudicate between the two views and begin to build their own case. This relies on a series of generic assumptions. Most importantly, it relies on the assumption that the 'rules' of the world being described are the same as the rules of the reader's 'zero-world'. In negative terms, the dead body cannot be asked who killed it, the murder has happened in the past and cannot be un-happened or viewed, and so on. A whole host of assumptions about how this world works are brought to bear on the text so that a reader can focus on solving the crime. In positive terms, some of Corwi's claims seem to mirror claims we might make about the 'zero-world', though of course the complication is that we are likely inheriting those beliefs not from the zero-world itself but from other texts within the genre. Nevertheless, the assumption is that a reader will be able to take part in reconstructing, with Borlú, the narrative which extends back in time towards the crime itself, while proceeding forward in time through the narrative as Borlú does. This short scene plays out the detective process in microcosm, demonstrating the "norms that usually underlie the classical detective story (and the genre in general), in particular that of epistemological certainty: the ability to reach a solution of the mystery by a process of rational and systematic thinking" (Segal 192).

However, many of the assumptions which underpin the genre are challenged when, at the end of the first chapter, Borlú encounters an Ul Qoman woman and the reader has their first encounter with the practise of 'unseeing'. This involves the often involuntary ignoring of objects which, despite being 'grosstopically' near the viewer, are in the other city. In this case, the woman is in Ul Qoma, so after a moment of looking, "with a hard start", Borlú realises that "she was not on GunterStrász at all" — i.e in Besźel — and that he "should not have seen her" (14). The encounter alerts a reader to the science-fictional, arealistic nature of the text, complicating the generic category of the (hard-boiled) detective novel. This calls into question the investigative work Borlú has done in the chapter up till this point. The note that the end of the street which Borlú takes to be GunterStrász "might be anywhere” takes on new, more complicated connotations after the realisation that the scene is more spatially weird than the till-then realistic genre would predict, but the connotations before that realisation are quite simple; this is a rundown neighbourhood, like one found anywhere. That description could easily apply to the crime scene itself, and for this reason our reading of the earlier scene is also complicated. A reader cannot, at this stage, know that Borlú's 'unseeing' applies only to Ul Qoma. At this stage, they have to wonder what else it is that Borlú unsees, and his quick, well-practised reaction suggests that this slip-up in seeing the elderly woman is a rare one. What had seemed an objective account of the crime scene is cast into complete doubt. Given that we know that Borlú habitually unsees 
physical details of the world around him, how can we trust that his vision of the crime scene is at all accurate? The "epistemological certainty" which Segal suggests is the central norm underlying the detective genre is challenged, as is the reader's ability to follow Borlú and discern using "rational and systematic thinking" the solution to the central mystery.

This complication dogs both Borlú and his reader throughout their investigation. The separation of the two cities is a constant obstacle. During his meeting with the Oversight Committee (who control which crimes are passed on to Breach), Borlú puts it plainly. Criticised by the nationalist politician Syedr for his apparent over-willingness to cede sovereignty to Breach by passing over the case, he replies 'Yes, I am keen. Don't you want to see the murderer of Mahalia Geary found?” (82). This is the culmination of Borlú's frustration with the case as a whole. The structure of Breach and the separation of the two cities has meant that he is unable to even share the information he receives via anonymous cross-city phone call (42), and must set Corwi on the right track through deception — as when he "as if idly" mentions that they might start looking at "unifs", political dissidents who advocate for the unification of the two cities (47).

By aligning a reader with Borlú in the shared desire to find Mahalia's killer and then posing the separation of the two cities as an insurmountable obstacle in that process, The City \& the City generates within its reader a desire to see that separation ended. This operates both figuratively, in that they want to see the science fictional elements of the setting clearly explicated, providing them with a solid and clear base from which to conduct their 'investigation', and literally. As Scott notes in Seeing like a State, the desire to read often shades into the desire to make legible (181) — reader becoming writer. If the two cities were to be unified and the practise of unseeing ended, then the setting of the text would more closely match that of the zero-world. This would allow the reader to bring more of their empirical knowledge to bear on the case, and would allow Borlú to pursue his investigation in person rather than handing it over to Breach. This resistance to higher, formalised power is one which is enshrined in the American police drama - think of the 'feds' proclivity towards showing up in black SUVs and 'taking over' - but is also a consequence of the genre-as-puzzle. The enjoyment of the mystery is in its solving, not in its being-solved. If Breach were to identify the murderer rather than Borlú and his proximate reader, that element of play would be denied.

Alongside establishing the desire to make legible (and the desire to escape mediated reality and directly access the real), The City \& the City also troubles and complicates it. It does this through including images of the double which, by being either emotionally difficult to 
collapse together or intellectually useful despite their clearly ideological origins, demand that their reader not simply desire to bypass them.

One such image is that of the 'DöplirCaffe', an image which Hanna and Cowley suggest "helpfully sets the agenda for our reading of Miéville's novel, which takes as its primary concern the management of intercultural relationships" (2). In a digression just after the opening scenes, Borlú explains that the 'DöplirCaffé' is a Besź cultural institution made up of "one Muslim and one Jewish coffeehouse, rented side by side, each with its own counter and kitchen, halal and kosher, sharing a single name, sign, and sprawl of tables" (26). This 'merging' is explicitly motivated by mutual oppression. Borlú thinks his way onto the subject of the DöplirCaffé by way of the racial slur "Ebru", the "antique Besź word for 'Jew"' which has been, in Borlú's terms, "press-ganged into service to include the new immigrants", and has "become a collective term for both populations" (25). This construction across the two pages and two discussions generates a complex symbol. On the one hand, the merged coffeehouse seems designed as a symbol of cultural blending — of a kind of internationalism which, recognising the ideological nature of the division between the two groups, renounces their difference. On the other hand, the preceding explanation of 'Ebru' makes it clear that this blending together is explicitly oppressive in nature. Viewed in this light, the imagined dividing line which splits the DöplirCaffé might be read as an act of political resistance in the face of a society which would flatten the two cultural groups together. This doubled image serves to trouble a reader's desire to similarly flatten the two cities together - the "panacea of unity and the utopia of razed boundaries", in Hanna and Cowley's terms (2). The suggestion is simply that not only are these (strictly ideological) divisions necessary elements of any 'map' of the real territory, but they also cannot be flattened together for ethical reasons. To do so would not be to promote a kind of cosmopolitan comradery - it would be to deny real difference.

Another image of doubling concerns Borlú himself, and his Ul Qoman counterpart Dhatt. The two are quickly established as rivals who must learn to work together in order to succeed - a staple of the American detective genre. As rivals, the two are also defined as much by their similarities as by their differences. This is established in their first meeting: like Borlú, Dhatt emerges "around and in front of the approaching officers" (157) who are his compatriots, both alone except for their respective drivers. Borlú's approach to the boundary between the two cities thus presents it as a mirror in which his reflection, complete with its own driver, takes the form of Qussim Dhatt.

The similarities continue throughout their working relationship. Most notably, the two live "within a mile, in grossotopic terms" of each other, so close that their houses overlook the 
same park (234). This closeness is not necessary in narrative terms. There is no Breach in which Borlú goes from his house to Dhatt's or vice versa. Their proximity here serves to remind a reader to treat the two men as symbolically linked - each a different-city version of the other.

However, the two men are also radically, incommensurably different. Perhaps the most striking difference between the two is highlighted by Borlú's response to what he describes as “robust interrogations" (199) — Dhatt's seemingly routine use of physical violence during questioning (195). This shocks Borlú into the neatly put phrase that "my own [face] was set, I suspect, from the effort of not showing anything" (197). This is a fundamental and deeply felt difference between the two, and demonstrates the point well. Despite the two men being symbolically established as doppelgangers, their placement within the two cultures - the one Besź, the other Ul Qoman — has produced two very different individuals. Ideological the difference between the two cities may be, but it is nonetheless an invaluable conceptual difference. Without it one would be unable to describe or explain the difference between Borlú and Dhatt.

Alongside these problematic images of the double, The City \& the City also includes two entities who dramatise the failures of instrumental rationality (in two quite different ways) — one David Bowden and the other Breach itself.

In the final scenes of the novel, Bowden is revealed as Mahalia's killer. While his motivation for the series of deceptions which lead to Mahalia stealing artefacts on behalf of Sear and Core is, at first glance, simply the desire for wealth, Borlú's conversations with Bowden quickly reveal that it is a complex psychological failure which lies behind Bowden's crime. In their final confrontation, Borlú intuits that Bowden's motivation for the murder was not to cover up Mahalia's discovery that Orciny does not exist, but rather that, in Borlú's words, "Mahalia died because she proved to Bowden that he had been a fool to believe the folktale he created" (359). Recognising this, Borlú is able to convince Bowden that he will not be satisfied leaving the two cities, and that to "see what's really in between" (362) he will have to let himself be brought into Breach. Bowden agrees, and so allows himself to be captured. This is a highly suggestive scene for several reasons.

First, it seems worth noting that Bowden, rather than any of his co-conspirators, takes the place of central antagonist in the novel. Where the centrist politician Buric and the CEO of Sear and Core, Croft, might be pointed to as the ultimate architects of Mahalia's death, Bowden occupies the emotional centre of the murder. Unlike Buric, who is only represented very briefly during the meeting of the Oversight Committee (71), or Croft, who we only encounter in his sneering pre-escape monologue (342), Bowden is familiar. He features in several scenes, and 
engages in long and detailed conversations. His attempted escape, in which he affects a mannerism and gait which are ambiguously between the two cities and place him outside the jurisdiction of either police force without committing Breach, is one of the most memorable of the novel's explorations of its science fiction conceit.

Bowden's book on Orciny, which might be supposed to be the ultimate cause of his crimes (representing, as it does, his obsession with the hidden third city and the "folktale he had created" (359)), is titled "Between the City and the City". This echoes the title of Miéville's novel, and thus operates as a kind of metafictional break. This metalepsis invites a reader to draw a parallel between their own desire to uncover a hidden meaning in The City \& the City — to see past the distortions of ideology — and Bowden's desire to uncover Orciny. This comparison is an uncomfortable one. Bowden, then, might be read as a cautionary tale. Alberto Toscano suggests that "the secret of real abstraction is precisely an open secret, one that is to be discerned in the operations of capitalism rather than in an ideological preoccupation with the concrete truth or hidden essence that the abstractions of capital supposedly occlude" (282). While Bowden's preoccupation is with the two cities rather than the abstractions of capital, Toscano's warning here seems entirely appropriate. By dramatising the failure of the desire to access the real in the figure of David Bowden, The City \& the City draws into question its reader's own desire to escape ideology through cognition.

Breach also seem to represent a failure of instrumental rationality. While the organisation is represented more sympathetically in part three of the novel, this does not seem enough to overcome its negative portrayal earlier. From a distance, Breach resembles a repressive secret police: they apparently operate a pervasive surveillance apparatus, they “disappear" people, and whatever mechanism for determining guilt they operate, it is concealed from the external scrutiny. Breach clearly violate the moral intuitions of a reader, and while an argument could presumably be made for their necessity, they are by no means a progressive force in the world of the text. Breach's internal structure, however, seems to preclude many of the expected reasons for their reactionary nature.

Breach are notable for their direct democratic decision-making. Borlú describes a "fast, loose" (317) voting process, in which votes are conducted in person, and are accompanied by rigorous debate and discussion. While the minutiae of this democratic process is never fully explored, one might imagine that it incorporates solutions to the more obvious issues which are usually attached to democratic systems. Perhaps there are tiers of decision requiring larger majorities, or some form of constitutionally defined delineation between the political and the personal. Regardless of the particulars of Breach's direct democracy, it at least seems to rule out 
any of the obvious perverse incentives associated with authority. Because Breach has no central authority, neither representative nor dictatorial, this does not seem to explain its character.

These issues of power are also made implausible on the level of the individual. While Ashil, who might be taken as a representative member of Breach, is portrayed somewhat negatively in the beginning of part three, his character becomes more sympathetic as the novel goes on. By the end, Borlú certainly trusts him, and could even be considered his friend, and this positive emotional connection is likely to extend to a reader through simple proximity (and this is only confirmed when Ashil is shot (341)). This seems to rule out the desire for personal power in Breach's motivations to the extent that Ashil is representative.

Moral flaws on the level of the individual are also made less likely by the fact that Breach are, apparently, made up entirely of former breachers, who are "recruited", coercively, in the same way as Borlú. The revelation in the last two pages of the novel that Borlú is being brought in to Breach further complicates the question of why Breach continue to act as Breach. Given that Breach are not constrained by force, neither from above (in the case of a central authority) nor by necessity of circumstance, and are not motivated by individual desire for power, their reactionary nature must be the result of flaws on the level of the organisation.

Breach, then, seem to perfectly embody a failure of the (Suvinian) desire to escape ideology. The agents of Breach are explicitly outside the cultures of Besźel and Ul Qoma, to the extent that they discard their names, which have etymological links to their previous cultures. They affect a dress and manner which marks them out as belonging to neither culture, and reside in spaces which are claimed by neither city. Most importantly, Breach's vision is not constrained by the requirement to unsee. Of all the groups in the novel, Breach get closest to an unmediated experience of the real. Their failure to act as a progressive force therefore serves as a significant challenge to Suvin's apparent belief that cognition will necessarily produce positive outcomes.

In the absence of the explanations discussed above, Breach's moral failure must be attributed to their epistemological position. If, as Althusser argues in For Marx, ideology and the mediation of reality are inescapable parts of human existence (232), then the belief that one has escaped ideology would serve only to instantiate a new ideology which is invisible to those who hold it. This seems to be the case for Breach, who continue to police the boundary between cities purely, it seems, because they cannot conceive of their doing anything else.

Finally, by way of a conclusion, it might be worth returning to the initial task of the detective by way of these various challenges and complications to the logic of cognition. Specifically, it might be worth returning to the question of whether the detective process is, after all, a process of cognition. Borlú's methods, it is true, often rely on the kinds of attention to 
physical detail (and their placement within a logical system or structure) which we might associate with rationality. His work often involves the reduction of the unknown to the known, or the ineffable to the effable.

Having said that, there are two complications to this image of the detective-as-rationalist. First, the degree to which Borlú utilises strictly physical evidence is relatively low. To take a simple example, one question which is hypothetically present throughout the entire investigation is the question of why the van which left Mahalia's body in the estate was full of old iron and debris. There is a clear progression, as if to signpost the debris as a clue: first, the forensic examiner notes the rust on Mahalia's skin (27). Then, the debris is discovered in the van, explaining the rust (32) — and Khurusch denies having put it there (39). Chapter Three closes with Borlú and Corwi puzzled by its presence and Borlús evocative observation that "all the rubbish had done was roll into the dead woman and rust her as if she, too, were old iron" (39). All the signposts of a useful detail are there, and the progression of information points into the future - it seems likely that the debris will add something meaningful to the ongoing process of detection. But then the debris disappears from Borlú's consideration. It reappears, finally, in his conversation with Bowden at the end of the novel, in which he notes that Bowden had picked it up in order to weigh Mahalia down (359) - and that it had been made useless by Bowden having an out-dated map of Besźel (360). This is a tendency with all the physical details of the early investigation, such as Mahalia's thick make-up which turns out to have been put on by Bowden. In fact, almost all of the useful discoveries are made not by careful, rational examination of the evidence, but by skilful navigation of the social space, and by the understanding of motive. Borlú is no Holmes - the case never rests on identifying the murderer's shoe-size, or favourite brand of tobacco. Rather than the instrumental rationality which Suvin has appeared to endorse Borlú might be read as practising a more 'socially embedded' mode of thought of the kind called for in "Cognition as Ideology" (241).

To take this decoupling of detection from instrumental rationality a step further, it might serve to examine what the process means for Mahalia. At the point of her entry into the narrative - when Borlú arrives at the crime scene and finds her - Mahalia is an unknown corpse - a body, rendered entirely within the realm of the physical: she, too, is old iron. As the investigation progresses, Borlú discovers details of the murder. In doing so, he gradually accumulates more details about Mahalia herself. This begins with her name, a metonym par excellence for identity more generally: Mahalia begins as an unnamed object, but is quickly assigned the name "Fulana Detail", a "generic term for an unknown woman" (10). She then has two pseudonyms 'returned' to her: first "Marya", the name she used in Ul Qoma, which Borlú learns from Jaris (43), and 
then "Byela Mar", the "elegantly punning" pseudonym she affected in Besźel. This second name does more than restore a label; the content of the label also restores to her body a degree of personality. There is something playful about the pun. The conversation with the unificationist Drodin in which "Byela Mar" is reattached to Mahalia (57-58) adds several more details of personhood. Drodin reveals that he had a fascination with her, and describes her as "intense" (60). While Borlú's process of detection is intended to render Mahalia knowable, in order to discover the identity of her murderer, it also clearly restores her identity — in fact, from the perspective of a reader, it restores her personhood. Viewed in this light, the act of murder might be understood as the pinnacle of cognitive rationalism - the transformation of human into object. By uncovering and bearing witness to Mahalia’s life, Borlú (in a sense) restores that life.

This rereading of Borlú's purpose in solving the murder, then, might suggest a path through the complex terrain which the novel has suggested, and a way to resolve the text's strange (by the writer's political standards) ending.

I think it would be fair to say that we like Borlú. We appreciate his melancholy, and his honesty — and we find his relentless pursuit of justice for Mahalia compelling. The novel relies on this identification with Borlú for its narrative charge. When, at the end of the text, he joins an organisation which internal structure aside strongly resembles a repressive secret police, this must give us some pause.

By putting these pieces together, though, it is possible to suggest a compromise. Despite the problems it poses to the project of cognition, The City \& the City can nonetheless be read as a novel which dramatises the need for some version of that project - see, for an example of a reading which emphasises this current, Freedman's reading of the novel as "deflationary" (104), pulling away from metaphysical towards the concrete. The tension between these two currents is embodied in the figure of Borlú, and in his admittance/recruitment to Breach. When he argues that they are "good at being bogeymen" but "shit at this" (324), the invitation is to read "this" as the process of detection — but Borlú's detective process is, in critical ways, not a rational process but a process aligned with the post-rational. Tentatively, we might expect that his introduction into Breach has more radical implications than simply to make them more effective at policing the boundary between cities. We might expect or hope that Borlú, as a figure of socially embedded cognition, could lead to Breach's total transformation. 


\section{Chapter Two}

\section{Romanticism after the Crisis: The Last Days of New Paris}

Having encountered or collided with the problems and problematics of the cognitive outside view in The City \& the City, and concerned especially with the problems that an inability to think our way out of ideology pose for efforts to imagine or design the future, the Miéville of The Last Days of New Paris (2016) takes the opposite tack, shifting attention towards the ways in which past epochs persist into the present and towards a criticism of modernity as such. This is an angle of particularly pressing importance thanks to the (delayed) impact of the $2007 / 8$ global financial crisis (GFC).

In August 2015, the editors of the newly-formed Salvage lamented that although "it was not naïve to expect that the crisis of 2008 would replace what we call 'neoliberalism' with a new, distinct phase", faced with the victory of the Conservatives in the UK general election, a result which they call "a worse outcome than the worst-case scenarios imagined by (almost) anyone on the left", that expectation seemed both naïve and deeply wrong. By January 2017, the situation had changed. From a situation in which it was reasonable to claim that neoliberalism was essentially unscathed had emerged a world in which, in Salvage's words, "not since 1943 has there been a better time to be a fascist." 'The editors go on: "The 'liberal order', the demise of which has been the subject of ruling-class hot takes for some years now, does indeed appear to be in a shabby state. Trump's election - on which more within this issue - follows on from the vote for Brexit as a body blow to the politics of the 'extreme centre' in the very lands in which it was born. Victory for the far-right Freedom party in Austria's presidential election was very narrowly averted: should Marine Le Pen win the forthcoming French presidential contest, against which no sensible punter would now bet, the resulting scrap of hard-won relief will evaporate" (Salvage 2017). At some point in the interim the GFC, evidently, lead to change, though not of the kind which Salvage wished for. On the other hand, glimmers of a different world are visible. As Salvage had noted in November 2015, Corbyn and Sanders' successes in the US and UK respectively (though only the former has as yet gone on to enjoy any real success) were also breaches in politics as usual - though Salvage is clear throughout that the attempt to connect, for example, Sanders to Trump or Corbyn to Farage in any simple sense is transparently 
motivated by centrist desire to hold on to power. This, then, was the landscape of 2015 and 2016: glimmers of potential opportunity, sunk into a morass of xenophobic reaction.

Miéville's The Last Days of New Paris (2016) can be read against these concurrent explorations of the crisis and its dangers, opportunities, and complications - a comparison which proves the novella's productivity as a text for thinking the crisis with.

The Last Days of New Paris is made up of two narratives woven together and a third which makes up the afterword. In the 'smaller', less prominent of the two narratives, set in 1941, Jack Parsons, a disciple of Aleister Crowley (the famous occultist) meets and stays with a group of exiled artists (including André Breton) outside Marseille. Parsons is en route to Prague, where he hopes to raise the famous golem of that city to aid in WWII. Having decided that that journey will not be possible, Parsons instead imbues the occult machinery with which he had hoped to raise the golem with the surrealist energies of the artists with whom he is trapped. Before Parsons can use the device, though, it is stolen by Raymond 'Killer' Couraud. Couraud travels to Paris where he tries to sell the device but is attacked. In the attack the device explodes, unleashing surrealist magic into the world and transforming Paris.

This unleashing and transformation forms the central novum of the text. After the explosion, which comes to be called the 'S-Blast', entities called 'manifs', surreal artworks come to life, take up residence in Paris. The S-Blast also pulls the Nazi allied demons up out of Hell and traps them in the city. From this point, the two groups fight for control.

The 'main' narrative is set in that radically altered Paris, in 1950. It begins with the French resistance fighter Thibaut deciding to leave the city, having given up on resistance. On his way out, Thibaut meets Sam, who initially claims to be working on a book documenting the city and is later revealed to be an agent of Hell, investigating the Reich for treaty violations. The two work together to uncover and finally destroy the Nazi project referred to as 'Fall Rot'. This project involved the creation of a synthetic demon, which the two kill only to discover that the demon's purpose was to be a sacrifice for the summoning of a Nazi manif, a self-portrait of Hitler. The self-portrait kills Sam, and is about to destroy New Paris when Thibaut defeats it with the help of another, genuinely surrealist manif.

In the final sections of the book an unnamed narrator, apparently from the 'real' world rather than the world of New Paris, talks about being introduced to a man he assumed was Thibaut and hearing the story of New Paris from him. The novella concludes with an index of artworks and academic sources on Surrealism in this unnamed narrator's voice.

A productive way to interpret the text, which this chapter will follow, might be to start from the position that the S-Blast, as a rupturing event which changes what is possible in the 
world, represents in loosely allegorical fashion the kind of crisis of which the GFC is a type: not a political event as such, but rather a changing of the landscape such that politics is radically changed. The entities which enter the world of 'New Paris', then, become representative of some of the political impulses and positions which likewise 'enter' through the gap opened by the GFC.

Although demons are only infrequently represented in the novella, some aspects of their appearances suggest that they might be taken to reflect a reaction against quantification, or against what Weber refers to as the "disenchantment" of the world (Löwy Morning Star 2). We might term this reaction "Romantic". In Romanticism against the Tide of Modernity, Löwy and Sayre define Romanticism as "a critique of modernity, that is, of modern capitalist civilisation, in the name of values and ideals drawn from the past (the precapitalist, premodern past)" (17), "characterized by the painful and melancholic conviction that in modern reality something precious has been lost, at the level of both individuals and humanity at large; certain essential human values have been alienated" (21). More specifically, they identify Romanticism as the sense that there has been the "decline of all qualitative, social, and religious values; the death of the imagination and the novelistic spirit; the tedious uniformization of life; the purely utilitarian relations of human beings among themselves and with nature" (35). This definition of Romanticism is, by necessity, a broad one - but this is, in effect, their thesis: that what is being pointed towards is a broad constellation of terms (imagination, qualitative, social and religious values) which stand in opposition to the desire to quantify and rationalise.

The Last Days of New Paris' demons, then, reflect this reaction against quantitative measurement through their exceeding of its terms. When the first demon to be 'shown' in the novella appears, the first aspect of its appearance which Thibaut notes is it's "swaying body, like a great bull" (17). Then, he notices its "many long, grey, random horns", and "meat-eater tusks" (18). Finally, in the strangest and most memorable detail, it "shambles painfully away on what seems a varying number of legs" (19). The details of the demon's body begin in a way which can be rationally accounted for, with its bull-like body, but quickly move towards details which exceed Thibaut's ability to count or quantify them; first the horns, which Thibaut does not count, and then the legs which are literally uncountable. The demon is a mobile breach in the accepted laws of reality; a walking impossibility².

The demons of New Paris also exhibit something of the "painful and melancholic" desire to return to their (abstract/imagined) homeland which Löwy and Sayre argue characterises

\footnotetext{
${ }^{2}$ The reading of the fantastical elements of a text as conceptual breaches in both social and material reality is a staple of thinking about Gothic fiction and the fantastical more generally - see e.g. Monleón.
} 
the Romantics. Thibaut notes that, despite their bluster, "the demons winced through their sneers. They rubbed their skins gingerly when they thought they weren't observed. When they killed and tormented it was in a faintly needy fashion. They seemed anxious. They stank not only of sulfur but infection. Sometimes they wept with pain" (Miéville The Last Days of New Paris 28). Trapped, like the politics which they represent, in modernity, the demons suffer and wish for their former home - a home to which they cannot return.

Later in the novella, Thibaut and Sam encounter the artificial demon which is initially believed to be (and for the sake of brevity will be referred to as) 'Fall Rot'. While Fall Rot does not so explicitly violate rationality, his appearance does incorporate a variety of symbols linked to a fascist ideology which venerates both warped social collectivity and a brutal, masculinist vitalism — what we might term in Löwy and Sayre's words 'social values'. Fall Rot is “a centaur of tank and great man-shape...festooned with German Flags." His body is "vast. He wears an outsized German helmet. His skin is cold white, his veins and muscles marked as if by wormtracks", and Thibaut notes that he is "made of Nazi triumph" (152). The overt, excessive displays of German nationalism here, coupled with his "cold white" skin, mark the demon out as a representation of the ideology, a fact which Thibaut's description recognises. Further, the demon fuses war machine with a kind of obscene muscularity. It does not speak in any human tongue: instead, its voice merges with the sound of its fire, so that after "a shell roars out", the demon "bellows" (151). When it does talk, it is in "what should never have been a language, spewing dirt and exhaust" (152). Like the earlier demons, Fall Rot does not inhabit the world of rationality, connected as that world is with language and countability. Instead, he emerges from a violent, pre-rational rage.

Having identified a Romanticist strand in the depiction of demons, the question becomes the degree to which this strand might have descriptive force when applied to current rightpopulists. Explanations for the populist surge are many and various. Perhaps the most obvious route is to blame the crisis itself, and to claim that the misery caused by capitalism's failure opens a gap into which a 'strongman' demagogue can pour misinformation and emotive rhetoric, inflaming old prejudices into a reactionary movement. For various reasons, this seems inadequate.

While it might be tempting (and many have been tempted) to dismiss Trump voters or supporters of Farage as simply irrational, a more productive reading might be to see this reaction as part of what Polanyi called the 'double movement'. In this reading, it is not the simply measured quantitative indicators of material well-being which are missing, but rather the less visible social fabric. As Löwy and Sitel put it, "it is necessary to avoid the purely economistic 
explanations of the rise of the right sometimes advanced on the left" (54). In their analysis, the growing success of the far right is best explained by "the process of capitalist neoliberal globalization - also a powerful process of forced cultural homogenization - which produces and reproduces, on the European and planetary scale, the identity panics, the obsessive search for sources and roots, leading to chauvinist forms of religion and religious forms of nationalism, each playing a role in feeding ethnic and confessional conflicts” (54). Geoff Eley, too, suggests that the underpinning process "is the underlying disorder of societal dislocation associated with contemporary economic change - less the immediacy of crisis since 2008 than the still unfolding consequences of fundamental capitalist restructuring since the 1970s" (111).

Populist sentiment thus seems to draw upon a discontentment with the affective, cultural dislocations brought on by modernity as much as from the material conditions (that is, personal wealth - this division is not intended to sever social or 'spiritual' conditions from their material bases) which it produces. On this basis the connection between the implied Romanticism of demons in The Last Days of New Paris and contemporary right-populists seems entirely valid.

This is not to say that the exploitation and poverty produced by economic systems and exacerbated by the GFC are not the primary driver of political discontent in the UK, Europe, and the US today. What is needed, though, is more than an explanation for right populism's successes in absolute terms. Any explanatory structure needs to explain populism's relative success, its seeming triumph over an (even toothlessly neoliberal) establishment Left. By focusing on the Romantic elements of populism's appeal as opposed to more straightforwardly economic explanations, this view avoids the kind of elitist position which treats the people as blind to their own interests. Rather than terminating in a suspicion towards democracy on the grounds that the masses lack economic expertise, as some on the supposed-left have done, the focus on the appeal of Romanticism points towards a genuine need which Left political movements are not contesting. This criticism of the left echoes one made decades earlier by Ernst Bloch. Anson Rabinbach, for example, argues that Bloch's Heritage of our Times "is particularly concerned with those ideological remnants of past epochs that have been appropriated by fascism not, however, to reveal their illusory character, but to restore them to their genuine place in a powerful, but fragmentary, anti-capitalist heritage” (5), a position which leads him to an "extremely heretical" question: "if the explosive tradition of mystical and romantic anti-capitalism was not merely composed of "irrational" and archaic myths, but dynamic and active components of the present, then didn't the impoverishment of the Left in regard to revolutionary fantasy make it an accomplice in its own defeat?" (6). This is a question which is crucial today. 
As if to imagine a Left which was not, in this sense, an accomplice in its own defeat, The Last Days of New Paris also represents another more sympathetically portrayed set of supernatural entities in the form of the surrealist manifs.

This is a connection which is remarkably straightforward given the politics of the surrealists themselves. As Löwy puts it in Morning Star, Surrealism is "a revolt and an eminently subversive attempt to reenchant the world", a "protest against narrow-minded rationality, the commercialization of life, petty thinking, and the boring realism of our money-dominated, industrial society. It is also the utopian and revolutionary aspiration to "transform life" - an adventure that is at once intellectual and passionary, political and magical, poetic and dreamlike" (1). The connection to Romanticism is clear, and the connection to the left equally as strong: as Löwy puts it, the "Hegelian-Marxist dialectic is at the heart of the philosophy of Surrealism" (Morning Star 2). "All Romantic Marxists", he argues, "struggle against the capitalist disenchantment of the world (which is the logical and necessary result of quantification, commercialization, and reification of social relations), but in André Breton and the Surrealists the Romantic/revolutionary urge to reenchant the world through imagination finds its most striking expression" (22).

Given this connection, it should be no surprise that, like the demons, the manifs of The Last Days of New Paris deny rational accounting. The exquisite corpse's body, the 'inspiration' for which is pictured on page 2 of the novella, is impossible to account for as a three dimensional object. The legs, especially, show their creation as collage: they are laid atop rather than connected to the machine part which forms the exquisite corpse's 'torso'. This spatial impossibility is simply not registered in Thibaut's narration.

The exquisite corpse also moves through space in a manner which is 'unaccountable'. When Sam and Thibaut first encounter the exquisite corpse, the three of them are immediately attacked. The means of the exquisite corpse's escape demonstrates its exceeding of rational space:

The exquisite corpse leaps. For the moment of its jump everyone on the Paris street feels as if they are on the mezzanine of a snake-flecked staircase.

The world torques-

—and Thibaut and Sam and the exquisite corpse are standing a long way from where they were. (65)

The exquisite corpse here simply moves through space in a manner which denies understanding. Like the varyingly legged demon, the processes of technical rationality are unable to 'grasp' it. 
This violation of the laws of rational space also characterises the "Soldier with No Name" (125). This manif always faces away from the viewer, a condition which remains true even when it is being looked at from multiple angles simultaneously. Like the exquisite corpse's leaps through space, it defies a viewer's ability to hold it to rational account.

The violations of physical law which characterise the manifs are also present in various other surrealist 'modifications' to Paris. The fate of the Eiffel tower post-S-Blast typifies this. In New Paris, the "tower's steepling top half dangles where it has always been... but halfway to the earth the metal ends. There's nothing tethering it to the ground. It hangs, truncated" (Miéville The Last Days of New Paris 11). Although the tower is only mentioned once in the body of the text, this is the image which has been chosen for the cover of the novella — most likely for its iconic Parisian qualities, but perhaps also because it stands as a perfect example of the way that the text deals with the usual world made incomprehensible in the wake of a shock.

What these imagined anti-rational, Romantic images, associated with the Left and linked to an emancipatory politics, point towards, especially in combination with the depiction of a fascist Romanticism which is much more clearly connected to an existing political movement, is the need for a Left which considers these affective elements of the political project. This is not simply to argue for an emotional appeal as part of political strategy, as if it were merely a case of getting the masses 'on board' - a position which implicitly casts the people as governed by emotion rather than intellect and legitimises something like an elite class. Rather, it is to say that any political project which is oriented towards an imagined future needs to incorporate affective needs within that vision. One potential rejoinder to this claim might be that the culture of the future society will arise from its relations of economic production rather than from any consideration of abstractions (such as an imagined need for "enchantment".) This does not seem to prove the case - presumably the Romantic might respond that if the cultural landscape of the society is produced by its economic organisation then those who are considering ways in which a society might be organised economically should bear doubly in mind the effects that that organisation might have on the cultural and affective landscape.

However, the suggestion that the Left has something to learn from the Right (and, worse still, from fascism, neo- or otherwise) should give a politically inclined reader pause. As the editors of Salvage put it, any opportunities for the Left in the post-crisis era arrive "utterly imbricated with brakes, hurdles, catastrophes, as part of a vicious wave of reaction" (Salvage "Not a Coup but a Blaze"). While the context makes it clear that Salvage is claiming these "brakes, hurdles, and catastrophes" as external obstacles and threats, the commonalities in The Last Days of New Paris suggest a deeper, scarier worry - a worry about goals as much as means. As Foucault 
puts it in the introduction to Deleuze and Guattari's Anti-Oedipus, "how does one keep from being fascist, even (especially) when one believes oneself to be a revolutionary militant? How do we rid our speech and our acts, our hearts and our pleasures, of fascism? How do we ferret out the fascism that is ingrained in our behavior?" (Foucault XIII).

As if he shares this worry, Thibaut seeks throughout the body of the novella to draw a clear categorical distinction between manif and demon. When he first encounters a demon, for example, he is quick to note that "It comes with nothing of that stir of recognition - even at something inconceivable that he has never previously seen - that a manif brings", and that "it does not move with the dream-like specificity of a manif' (18). These descriptions are essentially unnecessary, in that a reader will easily infer that the "thudding, broken step" with which he describes the demon in positive terms necessarily implies the negative description of being "not dream-like" (18). Thibaut's consistent comparisons thus seem to betray his own anxiety more than they aid his descriptive precision.

Thibaut's anxiety in this respect also emerges when discussing the shared origin of the two. He describes the demons "hurtling out into the world as the manifs did, though they were not like them, nothing like them, though the explosion had palpably been not of their nature" (27). This assertion, with its repetition of "not like them, nothing like them", seems intended to efface the obvious claim that the shared origins of the demons and manifs in New Paris, the SBlast, implies that they have at least something in common.

Where the assertion of a commonality between demon and manif (and the criticism of the contemporary political Left which this implies) seem directed at a purely economistic viewpoint, Thibaut's anxieties and their undermining seem pointed in the opposite direction, towards a Romanticist reader who underestimates the difficulty in, as Foucault puts it, 'ferreting out' one's own fascisms - a challenge which is compounded when explicitly borrowing from fascism's appeal.

Thus, Thibaut's attempts to draw a clear and categorical distinction between demon and manif — in the terms of the analogy, between Left and Right Romanticisms — are consistently denied. This is clear in some sense from the start: despite his insistence that demons are "nothing like [manifs]", he nonetheless describes them "hurtling out into the world as manifs did" (27). The two thus clearly share an origin, if nothing else.

The origin of the origin of the supernatural elements of the setting - the origin of the SBlast - also betrays the shared heritage of demons and manifs. The bomb which results in the transformation of Paris was produced in a collaboration between the exile-in-waiting artists in Marseilles, and Jack Parsons, who supplied the occult machinery which transformed artistic 
desire into real transformative energy. Parson's allegiances are not to Surrealism, but rather to the occult. He notes, for example, that he is a disciple of Aleister Crowley. More tellingly for asserting a connection between Parsons and Hell (and following the symbolic logic hopefully established here, the romantic origins of fascism), Sam describes Parsons at one point as "a buffoon who thought he was one of ours" (146). The connection must be closer than Sam admits here, however. Parsons notes that the strength of his magic is increased in France postNazi/demon invasion. This suggests that, whatever Sam might assert, there is a strong connection between Parsons and Hell. That Parsons is so involved in causing the S-Blast, then, suggests a close connection between the forces which unleash manifs and surrealist 'magic' into the world and those which result in the coming to power of the forces of Hell and fascism.

Another moment which casts doubt on the clean distinction which Thibaut wants to draw between manif and demon occurs early in the text when, having heard that there is a nest of demons in the ninth arrondissement (23), Thibaut's Main à plume cell seek them out in order to exterminate them. Upon arriving, they find a "trumpet-nose beast with fish eyes", swinging a cudgel in "brutal percussion", a "legless thing with bat wings" and a "spiked and suckered tail", and various other horrors (26-7). However, what seems to be obviously demonic is revealed to be, in fact, a manif - it is "living images. Images of demons, and of their victim" (29). The realisation causes a moment of discord: Pierre, one of Thibaut's companions, is initially unconvinced by Thibaut, and when he is persuaded it is reluctantly:

"No!" said Pierre, bringing his rifle back up. "Fucking bullshit," he said, and aimed again. But he did not fire, and his comrades watched the scene repeat, until Élise gently pushed his gun down.

The short scene is particularly interesting for the dynamics it implies. Pierre's disbelief seems, initially, difficult to understand, since presumably the lack of demons in the ninth arrondissement is to be celebrated. Why, then, his reaction? Two possibilities suggest themselves. First, Pierre might be expressing a straightforward desire to act. This might suggest a certain anxiety around concrete political action and its particular pleasures - surely political action which one enjoys should be somewhat suspect. On the other hand, one might read Pierre's reaction as displaced anger at the possibility of having mistaken friend from foe. In this reading, it is the lack of clear distinction between demon and manif which produces his angry reaction.

Further undermining Thibaut's insistence on the clear distinction between fascism and Surrealism is the existence of the manifs called "aeropittura", which Thibaut describes as "rushing futurist plane-presences", and even as "actual fascist manifs" (51). The existence of 
these manifs, no matter how marginal — and Thibaut attempts to dismiss them as 'not counting' on this basis (51) - clearly violates his attempts to draw clear lines between fascism and Surrealism.

These dynamics are repeated in a conversation between Sam and Thibaut which acts as a microcosm of this central tension in the text. The two argue about the shared backgrounds of her Hell-derived (though Thibaut is unaware, at this stage, of that connection) occultism and his Surrealism. Sam describes how her interest in Surrealism developed, and uses that description to make her case:

"First it was monster pictures," she says. "Devils and Bogeymen. Witches, alchemy, magic. Then from there to here [surreal Paris]. I'm hardly the first to come that way. Think of Seligmann. Colquhoun. Ernst and de Givry? Flamel and Breton? You've read the 'Second Manifesto.' 'I ask for the profound, the veritable occultation of Surrealism."'

"That's not what he meant by that," Thibaut says.

"He said he wanted to find the Philosopher's Stone!"

"And he said he wanted to lose it again."

They look at each other. Sam even smiles.

"From devils to Bosch to Dalí," she says. "From him to all this. To the manifestoes". $(59-60)$

Sam's playful misreading of the term "occultation" here serves to make her case stronger — in this instance, it is her who falls on the side of the fluid and creative, where Thibaut is forced into making an essentially formal argument from definition and intent; where Sam reinterprets, Thibaut simply repeats. Given the terrain of their disagreement, this lends considerable weight to Sam's argument.

What the brief discussion reveals is telling. On the one hand, Sam's argument is persuasive, and in the light of her connection to Hell, one might read her argument as making the case for the shared origin of the two movements. On the other hand, Thibaut's resistance to that conflation reveals some of the anxieties and tensions which a Romanticist Leftism must (and, presumably, should) contend with.

Undermining Thibaut's attempts to draw a clear distinction between the two similarly denies a reader the ability to too quickly dismiss fascism. Assuming that, contra Žižek's claim that "the very predicate 'proto-fascist' should be abandoned" since "what makes Nazism repulsive is not the rhetoric of the final solution as such, but the concrete twist it gives it" (138), 
this dramatically increases the importance of identifying a position or factor which will allow a reader to draw the distinction which Thibaut has failed to.

One potential way of doing so might be to suggest that fascism is distinct from a genuinely progressive politics by virtue of its orientation towards the past. As if to provide some early support for this distinguishing factor the role of technology in the representations of manif and demon is, for most of the novella, markedly different.

Throughout the body of The Last Days of New Paris what few demons are depicted are represented as animal organisms. They take strange and distorted forms, and (as discussed above) forms which exist outside of one's ability to rationally account for, but are fundamentally animal. For example, despite its bizarre numbers of legs and horns, the first demon encountered in the text is clearly a distorted bull (17). Likewise, the demon which Thibaut and Sam encounter on their way out of central Paris is "a thing like a shrunken man with a shrunken horse's head" (142) - here a combination of two 'natural' or animal forms, placed together and made disconcerting through the use of the adjective "shrunken".

On the other hand, almost all of the manifs represented in the novella are hybrids of animal and 'technology' (in the loose sense). This is especially the case for the most prominent and memorable manifs. See for example the "most famous manif of Paris, the elephant Celebes", "like a gray-ridged stockpot the size of a warehouse, under the howdah of geometric shapes, bull-horned trunk swaying like a small train" (56), which combines the natural image of the elephant with the synthetic stockpot. The description which Thibaut gives of Celebes also, perhaps, suggests its inanimate nature: it is "the size of a warehouse", and sways "like a small train". The symbolic vocabulary which Thibaut reaches for here suggests industry more than animal. Other manifs also follow this animal or human and technological hybridity model: the 'amateur of velocipedes' (a hybrid of the human with the machine in the form of a bicyclecentaur) (4), sharks with canoe backs, and so on.

The most prominent manif, the exquisite corpse, is also made up of a collage of animal and technological forms:

It stands like a person under a great weight, swaying on two trim legs. At its waist it is made of lines, offcuts of industry. A tilted anvil-like workbench, bits and machine pieces higher than Thibaut's head. He stares up at a pole of fetish objects. A clamping bench on engine parts on patient human feet. At the top of it all, an old man's too-big bearded face looks down at him with obscure curiosity. In his beard, a steam train the size of a cudgel, its chimney venting smoke into the bristles. The old man wears a larva on his head. Some limb-long bright caterpillar, gripping an outsized leaf. It wriggles and the leaf-hat flutters, hedgerow chic. (64) 
Like the amateur of velocipedes, the exquisite corpse sutures together the human (and especially here the face, which we might think of as the quintessentially human) with the machine (expressly "offcuts of industry" and the train, both suggestive of industrial modernity) — and like Celebes, also includes animal parts. So far, then, a distinction between manif and demon on the basis of their incorporation of technological elements indicative of modernity seems tenable.

However this distinction is complicated, if not totally undermined, by the appearance of Fall Rot. Where all previous demons have been depicted as purely biological in form, Fall Rot is much more complicated. While he can be read, as discussed above, as representative of fascist anti-rationality, it is also a hybrid. In this case, a kind of "centaur of tank and great man-shape", its lower half made up of "a Panzer III, stained by conflict" (152). While Fall Rot's 'technological' parts are distinct from those of the manifs by virtue of being specifically of the technology of war, this does not allow a dismissal of fascism on the grounds of its relation to the past.

Retrospectively, the revelation of fascism's potential future-orientation has been foreshadowed throughout. While the demons represented in the novella have all taken animal or biological forms, there have been constant minor suggestions of a connection between Hell and technology. For example, at one point Thibaut encounters a Nazi vehicle which has been modified to run on blood, and Sam suggests that "they must've refit it with the help of demons" (66). Similarly, Fall Rot is finally defeated by the application of Hellish technology in the form of an air-raid from beneath the earth. The explosion is prefaced by "a screaming across the below as if a plane races through caverns and tunnels" (156), a detail which links this attack from below with the contemporary experience of the air raid, placing Hell's intervention within the realm of conventional warfare as opposed to any magical or occult attack.

Fall Rot's hybridity thus suggests a complication, if not outright denial, of the straightforward attempt to attribute fascism to any purely irrationalist, anti-modern foundation. This is a relatively common route to explanation: see, for example, George Mosse's description of Nazi ideology as "an ideology which stood opposed to the progress and modernization that transformed Europe" (16-17), or Susan Sontag's argument that "fascism "stands for...the ideal of life as art, the cult of beauty, the fetishism of courage, the dissolution of alienation in ecstatic feelings of community" and "the repudiation of the intellect" (96), among many others.

The hybrid figure of Fall Rot, which is presented at first as the pinnacle of fascist ideology (within the terms of the allegory), strongly opposes this view through its representation of fascism as being an attempt to hybridise the past (here figured as natural/vital) with the future 
(here figured as the tank, at this point emblematic of military technology and 'progress'). While the manifs' representation as hybrids of animal/man and machine does suggest the need for a Left politics to forge an alternate modernity, this is not enough to distinguish it from fascism. The Last Days of New Paris thus denies a reader the ability to easily dismiss fascism and the potential for fascist-like failures on their own part on the grounds of fascism's irrationality and desire to return to an imagined past.

At this stage a particular reader of The Last Days of New Paris might be left with the pressing questions with which they began: the question of how to differentiate on the level of theory — that is, before the question of outcomes — between fascism and a genuinely emancipatory, future-oriented yet Romantic-influenced politics. That this is possible is clearly indicated in the novella's main narrative's final twist.

As if to assuage any concern that the novella will deny all possibility of distinguishing between Romantic Leftist thought and fascism, Fall Rot's defeat is followed by yet another 'twist', in the form of the revelation that the creation of the artificial demon Fall Rot was not the aim of the Fall Rot program, but rather that the demon was intended as a sacrifice which would 'wake up' a Nazi created manif — the portrait of Hitler. Hitler's portrait, replacing the Völkisch Fall Rot, clearly represents a betrayal of the Romantic impulse which initially motivated fascism. What is terrifying about the portrait is its gaze, which transforms what it looks at into a "cloying imaginary" - "prettier, more perfect" facades of Parisian streets (162). This effect is placed in contrast to the messy image of the Romantic or surreal city, but also in contrast to the Völkisch heroism of the demonic hybrid. Thibaut notes with horror that "this is what the Führer's selfportrait proclaims": "an empty city of charming houses" (164). As it crosses Paris "the watercolor will raise a quaint city. And everything will end. The struggles of the manifs, the angry smoke, the muttering walls, the fighters for conviction, the partisans of freedom and the degradation" (164). If it were at all needed, the moment in which fascism terminates in this bland vision of an empty future decisively denies its Romantic potential. Having complicated, undercut, and problematised all attempts to draw clear distinctions between surreal and fascist, between manif and demon, this moment at the climax of the novel definitively asserts the need to draw such a distinction regardless.

The assertion of this need is then followed by the assertion of its possibility. Faced with the portrait of Hitler, Thibaut is able to defeat and destroy it simply by throwing the severed head of the exquisite corpse which has been his companion at it. The too-large head of the surreal manif falls over the portrait's own head, blocking the "unembellishing gaze that fixes the ruins into nothing" (165). As the portrait struggles with the exquisite corpse, it is "remade", 
overwritten by the surrealist manif's body, and in the wake of this remaking "the buildings that it saw into twee perfection are less perfect again. They quiver", "they remember their cracks. And then with breaths of stone-dust they are back to ruination, or are not there, or are battered by age, scarred with the stuff of history, again" (166). In the terms of the loose allegory which this reading has advanced, this moment is a clear reassertion of the possibility of a Romantic, utopian moment - a depiction of a better possible future.

However, the utopian moment is made vague and distant almost to the point of absurdity. This reflects, perhaps, an intuition that "there is a smaller risk of imposing one's vision of the good upon others if this vision itself has fuzzy outlines" (Vint "Possible Fictions" 227), an argument which is explored in vastly expanded terms in Jameson's Archaeologies of the Future: as Jameson puts it, if "we must conclude that the search for a minimal Utopian demand, a universally acknowledged zero degree of Utopian realization...cannot escape the force-field of ideology and class-situatedness", then the "fallback position" for a thinker "confronted with the multiplicity of Utopian concerns which we have discovered to be in violent opposition to each other, is evidently the pluralist one" (175). Even taking the moment in which the head of the exquisite corpse 'overwrites' the portrait of Hitler as a loosely allegorical moment in which an emancipatory, surrealist politics triumphs over fascism, the novella goes to great lengths to distance this moment from the representation of any 'real' political moment. It is filtered: first through the imagery of the allegory itself, and then through the projection of even that fantasy world 'away' another ontological layer through inclusion of the afterword. What had been presented as a fantastical intrusion into an otherwise historically accurate representation of the world we live in is revealed to be a depiction of another world entirely - a world which only intersects with the fictional representation of 'our world' through the wandering figure who may not even be Thibaut. Further, the account presented in The Last Days of New Paris is not Thibaut's direct account, but rather that of an unnamed narrator who has only the scrawled notes from a night's listening to work from (178). This narrator is a writer of fiction, and acknowledges that they have not restricted themselves to "the most terse and dispassionate, even verbatim reportage of what was told me" (178). What a reader is given, then, is not only a fantastical allegory, but one which takes place in an entirely different world, reported Chinese-whispers-like to them third-hand by a writer of fiction.

Having established this succession of distancing devices, each of which insulate the text from the 'real' world of its reader, the novella's afterword performs a curious reversal. The narrator sees a man standing outside the café he is dining at, positioned in such a way that an apple blocks his view of the man's face. The image is a strange one: the man is "coated and 
hatted, unmoving. The apple obscured his eyes, his nose, his mouth", and yet the narrator is sure that the man was staring at him. Faced with this encounter, the narrator concludes that "perhaps some understanding of the nature of the manifs of New Paris, of the source and power of art and manifestation, may be of some help to us, in times to come" (182). The implication is that the man outside the window is a manif — that it is, in fact, a manif derived from Magritte's Le fils de l'homme (1964). For the reader who does not recognise this reference, the text provides plenty of other evidence. The way in which the man is described bears a striking resemblance to some of the other manifs of New Paris, especially the "chess-board man" seen in the film of the Nazi experiments. That figure "might have been a man holding a board in front of his face, even has a hand to the board's base, but there is something in his stillness. Thibaut knows he is looking at a manif' (125). The comparison with the man behind the apple is clear — despite the fact that the image need not imply Surrealism, the composition suggests it. Like the man with the chessboard, the apple-faced man is "unmoving" (182). Perhaps there is also "something in his stillness" (125). The narrator's suggestion that "some understanding of the nature of art" might be needed, directed at the reader of The Last Days of New Paris, drags the question of utopia back through the diegetic layers in which it was muffled. Rather than simply expressing the impossibility of imagining, The Last Days of New Paris thus demands that imagining is begun and, I would argue, makes itself available as a technology for facilitating such an imagining. How, then, to find the categorical distinctions which Thibaut failed to? By what principle might one ferret out the fascism in one's self?

Two elements of the text which have thus far gone unremarked suggest the shape of a possibility. The first might be found in the radically different relationships which each group forges with their supernatural counterparts and with the supernatural more generally. The Nazi relationship with the supernatural is characterised by the desire to control. When Thibaut first meets Sam, for example, she is pursued by "wolf-tables" controlled by Nazi handlers. When, in the attack, the wolf-tables falter "a Nazi cracks a whip, to rally them, to gather them" (35, emphasis in original). Later, Thibaut exclaims with surprise that they were "doing what they were told' (36). The use of italics for emphasis in both Thibaut's direct speech and in his free indirect discourse here registers his surprise at seeing manifs controlled, but also perhaps a sense of that control being somehow sacrilegious.

This sense of sacrilege is also evident in Thibaut's reaction to seeing the woman riding the amateur of velocipedes: "'My God', Thibaut thinks, "because a woman was riding her, and that absolutely should not happen.” (4). Again, the use of italics suggests Thibaut's shock. 
Later, Nazi soldier's attempt to snare the exquisite corpse: they have "nets and strange engines" - "a lasso whips and snares the manif" (65). Thibaut also uses a whip to interact with the exquisite corpse, but the relationship is dramatically different: "Thibaut has unwound his cosh and dangled the table-wrangler's cord around one of the manif's metal extrusions, which are not quite limbs. It is not a leash — it is not taut and Thibaut would never consider pulling but he has one end of it and the manif does not object to wearing it, and joined by the bond the living art comes with Thibaut as though he holds its hand" (67). The difference is clear: where the Nazi approach to the manif is to control, Thibaut's is a relation of mutuality characterised by the absence of domination.

This distinction in terms of physical domination and control is matched by the attitude of intellectual domination which the Nazi forces take towards the manifs and demons. Alongside their desire to physically control the supernatural, as in the case of the wolf-tables, the Nazi scientists depicted in The Last Days of New Paris work to understand manifs: they vivisect, for example, a number of exquisite corpses (126), and perform various experiments on them. The act of vivisection especially stands as a figure of the commonality shared by physical and intellectual domination. When a manif is vivisected, the particular and unique manif is subjected to extreme violence in order to both bring it within the order of the known, and also to establish and place it within a newly instantiated category of 'the manif', a category which the vivisectionist is establishing the characteristics of. These characteristics might be productively thought of as boundaries rather than traits, such that the vivisectionist is aiming to precisely map what is and is not a manif. In contrast, Thibaut exhibits no desire to understand where the manifs come from or how they work. He simply accommodates them into his life.

The distinction between Surrealism and fascism on the grounds of their differing attitudes towards intellectual subsumption allows for a formulation of what might be termed the ethical principle of the novella, a 'rule' which allows for an understanding of the distinction between fascist and surrealist thinking. Following Derrida, this principle might be termed an ethics of mourning - a term which requires some explanation.

Simon Critchley summarises the central part of Derrida's argument in Spectres of Marx as the dual observation that, on the one hand, "Marx respects the spectrality of differance at the basis of any conceptual order, political regime or mode of economic organization” (145), and that there is therefore "a logic of haunting" to Marx's thought (146.) On the other hand, Derrida also identifies in The German Ideology a desire to "be rid of phantoms and spectres" (Critchley 146). These two readings are not equally weighted: while Derrida is "reading with two hands", hauntologie has theoretical (and, I would add, normative and ethical) priority (Critchley 147). 
Derrida's project in Spectres of Marx is thus to revitalise Marxism's spectrality; both in the sense of conjuring the ghost of Marxism at the moment of its apparent death and in the sense of drawing out Marx's own logic of spectres against certain iterations of Marxist thought — which Critchley refers to as a "totalitarian... refusal of spectrality" (149).

What Derrida proposes, then, is a 'logic of haunting' in which politics can be founded on "the messianic appeal for justice conceived as a relation to the irreducible singularity of the other" (Critchley 158). That relation of irreducibility, in Spectres of Marx, is imagined as an attitude taken towards a ghostly figure which is neither entirely present nor entirely absent. This is both an observation of the instability of any given ontological category and an ethical injunction to maintain an aporetic attitude towards the ghost in which it is neither banished into the realm of the unreal nor incorporated into the realm of the real. From this we might generalise, with Critchley, from 'the real' to 'any conceptual order, political regime, or mode of economic organisation'.

One major advantage of suggesting a position on an ethics of mourning as the key distinction between Surrealism (as the figure of an imagined emancipatory Left Romanticism) and fascism is that it allows for an explanation of the novella's (perhaps) most puzzling question: the question of why Thibaut 'betrayed' his comrades in La Main à plume. This betrayal takes the form of two separate but connected actions.

The first action comes at the beginning of the novella, when Thibaut, despite being "loyal Main à plume", keeps the playing card which he is given "without letting his comrades see". Importantly, Thibaut "could not have said why" (7).

In a second 'betrayal', Thibaut refuses to go to the aid of his teachers and comrades. When a messenger from other Main à plume cells arrives, "almost brittle with excitement", and calls on Thibaut to "join us", that there is "a plan", Thibaut tells her instead, to her "shock", that he is instead "protecting the ninth" (50).

Later, after the assault which he had refused to join has failed, Thibaut thinks of his refusal to join and his keeping of the playing card as one and the same betrayal. He calls it "treachery against the collectivism, the war socialism of Main à plume" (97). What is consistent about Thibaut's failure to act is the sense that he does not know why he acted the way he did and is deeply aware that it went against (what he thinks of as) his ethos.

However, certain signs suggest that Thibaut's actions were not as against his philosophy as they might appear. Thibaut and La Main à plume's 'magic', which is to say their practice of Surrealism, involves "disposibilite" (35), the giving up of rational control. Thibaut has "learned to obey such intuitions" (79). This is the context in which his inexplicable decisions must be read. 
The outcomes of his betrayal are not entirely negative; it is later revealed that the plan which he was asked to join was a trap, at least according to Sam (147) — so while Thibaut could conceivably have saved his friends, it would not have been a great triumph but merely an escape. Instead, Thibaut plays the card to get out of an ambush with Sam (108), and in the process forces the Nazi bishop Alesch to flee and leave behind evidence of Fall Rot (109). In a roundabout way, Thibaut's playing of the card at that particular moment leads to the defeat of the portrait of Hitler at the conclusion of the novella. These two factors, taken together, do not paint a picture of Thibaut's narrative arc as one in which he initially fails his comrades through overcaution, as he thinks himself (98), cowardice, or greed, and then redeems himself through 'saving' New Paris, but a rather more complex narrative in which Thibaut's 'betrayal' must be treated as having been motivated by objective chance, having been 'surrealistically' correct, all along. By treating 'La Main à plume' as both a social body and as an ontological category, Thibaut's resistance to being completely integrated into the social body can be made equivalent to his resistance to incorporating the surreal into the categories of knowledge which allow him to define the physical world. In the terms of mourning, Thibaut's resistance to subsumption places him in the position of the ghost who transgresses the boundaries of La Main à plume. What, then, are the implications of 'mourning' in this sense as a guiding ethical principle?

Perhaps the most straightforward implication involves the question of the present. This is the sense in which the term hauntological has entered the language. Critchley describes, for example, "the insomniac experience of being haunted by the spectres of the past" (155). Likewise, Miéville describes hauntology as the "spectral rebuke that there was an alternative, once, so could be again" (Miéville "M.R. James and the Quantum Vampire”). These conceptions of the hauntological draw heavily on Benjamin's concept of dialectical images as "those objects that resist incorporation into a triumphal story of capitalism as endless progress and that therefore express (in their very quality as trash) the frustrated utopian fantasies of a particular generation" (Pensky 187). In this sense, the demand of mourning is to hold the past within view, an act which inevitably demonstrates the contingency of the present. The Last Days of New Paris serves this particular purpose through its exhaustive catalogue of surrealist artworks. By keeping these earlier expressions of a Romantic and revolutionary desire 'alive', the novella exposes its reader to the knowledge that a different world is possible. However, while an emphasis on contingency and the preservation of the possibility of change is a necessary pre-condition for change, the work of mourning seems to me to have further, more radical implications.

The refusal of subsumptive logic on the individual level seems to rule out the possibility of fascism - to act as a kind of memetic vaccination against it. The resistance to forming strict 
ontological categories, especially of people, has a clear and obvious implication for the problem of fascism. While it is possible to, as discussed above, search for explanations of fascism in a variety of often mutually exclusive or seemingly contradictory places, it is uncontroversial to state that fascism requires, as a basic condition of its existence, the definition of an in- and out-group; that is, the formation of a group which is Same and a group which is Other. By insisting on the refusal to consider the singular human in terms of their group identification, an ethical position like that put forward in The Last Days of New Paris undercuts this condition for fascism's existence.

The second implication of this ethical demand is an inversion of the first. The refusal to incorporate the other into the order of the same also demands that the self not subsume itself into the collective will. This demand further undercuts the possibilities of fascism's existence by denying the possibility of the coherent in-group. The demand, here, is for a steadfast refusal to not dominate (either epistemologically or literally) which is matched by a steadfast refusal to be dominated. As Brown notes, this is in common with "the surrealist commitment to an eternal process of unfolding", which he calls "a radical anti-institutionalism (not in the sense of a refusal to engage with, or participate in the creation of, institutional forms but in the sense of a commitment to their fluidity" (12)). As he points out, however, this commitment "quickly made their relationship with the Third Communist International a fraught one" (12), a challenge which Thibaut's eventual success does nothing to deny.

This is not to say that it is possible to simply derive from the ethics of mourning any kind of programmatic blueprint for the future. In fact, part of what the ethics of mourning seems to have ruled out is the very question which motivated its inclusion here: the question of Romanticism. If we follow Löwy and Sayre in ascribing the desire for an alternative modernity to, rather than a straightforward reaction against rationalism, a desire for "certain social, and religious values" (35), then the arrival at an ethics of mourning is an ironic twist. There is a strong sense in which Derrida's position corresponds more to the decoding movement of capital than to its Polanyian reaction - such that Critchley, for example, can identify in his thought a "persistent deconstruction of the concept of the frontier, the nation and territory. If there is a deconstructive politics, then it is de-territorialised" (114). As Mark Fisher puts it, "the left needs to argue for a model of collectivity which doesn't depend on a backward-looking and insular notion of community" (Fisher and Gilbert 100). While an ethics of mourning might preclude the worst excesses of Romanticism, it does nothing to provide an answer to the questions posed at the end of Romanticism against the Tide of Modernity: 
Is an alternative to "real modernity" possible? Can the desperate recourse to drugs, religious fundamentalism, or xenophobic nationalism be the only response to the social disarray created by the reign of market rationalism? How can we escape from the binary logic that compels us to choose between tradition and modernity, between returning to the past and accepting the present, between obscurantist reaction and devastating progress, authoritarian collectivism and possessive individualism, irrationalism and techno-bureaucratic rationalism? (Löwy and Sayre 252)

These are questions which are echoed by Derrida throughout Politics of Friendship, and which are expressed most simply in the questions with which Derrida closes that text: "is it possible to think and to implement democracy, that which would keep the old name 'democracy', while uprooting from it all these figures of friendship (philosophical and religious) which prescribe fraternity: the family and the androcentric ethnic group?" (306).

While The Last Days of New Paris does, then, call for an alternative modernity and provide some guidance for imagining and achieving it, it ultimately acts more to force these questions and the space they occupy open for further thought. 


\section{Chapter Three}

\section{Against the Individual Subject in This Census-Taker}

Like The Last Days of New Paris, This Census-Taker evinces a suspicion towards the instrumentalising logic of rationality. However, where The Last Days of New Paris associates this instrumental rationality with capitalist modernity as such, This Census-Taker draws a connection between the logic of subsumption and the operation of the state through its deployment of the census as subsuming agent. The novella's resulting emphasis on heterogeneity, multiplicity, and ambiguity in opposition to subsumptive centralised power places Miéville within the constellation of thinkers and politics associated with what Jeremy Gilbert calls the 'anti-capitalist movement'. Gilbert describes this movement as comprised of two central qualities: the "refusal to subsume multifarious struggles into one overarching identity", and the "demand for concentrations of power (both State power and corporate power) to be broken down" (94).

This 'anti-capitalist' position has faced a series of significant criticisms in recent years from Jodi Dean in her three texts Democracy and other Neoliberal Fantasies (2009), The Communist Horizon (2012), and Crowds and Party (2016). Dean's central argument in Crowds and Party is that the focus on individual freedoms and democratic decision-making which characterises the contemporary Left renders it unable to challenge dominant political powers. Drawing on her experiences with Occupy Wall Street, Dean suggests that the movement failed to live up to its political potential because "the individualism of its democratic, anarchist, and horizontalist ideological currents undermined the collective power the movement was building. Making collective political action dependent on individual choice, the "theology of consensus" fragmented the provisional unity of the crowd back into disempowered singularities" (11). Dean's argument is for the crowd as the political subject capable of changing the world, and for the Party as the vehicle capable of allowing the crowd to 'see itself — that is, to persist between distinct iterations of the crowd's desire for 'absolute equality'.

What is particularly interesting about Dean's claims for the necessity of both crowd and party is the ways in which her argument for their need as vehicles for revolutionary political potential mirrors the arguments made for community as the agent of real human flourishing. Indeed, Dean's description of the party as 'affective infrastructure' blurs these lines — her 
argument is ultimately that the sense of solidarity imparted by party membership and practise is needed for revolutionary success, but along the way she also implies that party membership aids in human flourishing for its members even before any political change has been accomplished. One way to understand loneliness, then, might be as a symptom of the powerlessness and lack of political agency which comes from isolation from the collective political subject. This lends Dean's argument some degree of support, since it allows accommodation of the idea that the line between pre- and post-revolutionary society is necessarily blurred. If, as the Romantic critique of modernity suggests, community is a fundamental consideration of a given utopia, then Dean's vision of the collective political subject has that to recommend it. It also means that the consideration of the need for community and qualitative value explored in The Last Days of New Paris and its complication by the novella's emphasis on deconstructive approaches to social organisation might be meaningfully transposed onto the question of the political subject.

On the other hand, Dean does almost nothing to address criticisms which the party form has faced. While she is successful, to some extent, in demonstrating a potential complicity which highly individuated Left politics has with post-Fordist capitalism, and thus in demonstrating the need for the crowd as subject, her relationship with the failures of the party form is much less convincing. In particular, her deployment of the 'iron law of oligarchy' to suggest that if "democracy means rule by the many, democracy is impossible" (Crowds and Party 143), even if true, rather deflates the entire project. (Farewell the withering away of the state and the control of production by the producers, at the least. On the other hand, the Left is, fortunately, familiar with demanding the impossible.) Rather than attempting a comprehensive criticism here, it will suffice to say that the suspicion towards political organisation which runs through The Last Days of New Paris places Miéville's recent work within a tradition for which Dean's turn towards the party is not adequate. The questions raised by Dean's criticism of horizontalism, then, remain live. While This Census-Taker does not necessarily propose answers to these criticisms, it is these questions which, in some important ways, motivate it as a cultural intervention. This is not to suggest that Miéville's political position is constrained from identification with the party form. Rather, it might be taken a sign of both the limits and the potentials of fiction as political intervention.

This Census-Taker depicts a relatively straightforward narrative: there is a boy, the narrator, who lives with his parents on a house in a hill above a town. The setting is, perhaps, fantastical, though it occupies the generic space of a text in which the characters believe in and practise magic but in which the magic itself is not necessarily 'real' (although this is complicated by the novella's paratextual connections: more on that later). The novella begins with the boy 
witnessing, perhaps, his mother's murder by his father. This murder is never proven, and so the boy continues to live with his father. Despite multiple attempts at escape with the aid of two friends, Samma and Drobe (poor children who live in the town), this situation persists until a census-taker from the father's former home arrives to talk to him. The census-taker hears the boy's account of his mother's death, (perhaps) finds evidence of her murder, (perhaps) kills the boy's father as a result, and the two of them leave. At the end of the narrative discourse, the boy takes up a position as the census-taker's assistant. The past tense narrative is broken by sections written in the present, in which the narrator discusses the situation in which the main part of the novella is being written.

Like The Last Days of New Paris, This Census-Taker works to connect the desire for total knowledge to the desire to control. A first hint of this connection is visible early in the novella, when the narrator recalls watching his mother garden. His mother had divided the garden into "seemingly formless plots with boundaries she marked with stones". Despite being told that she was "following contour lines" — allowing herself to be guided by the natural, immanent properties of the space — the narrator is "confused" (7), and finds that his mother's "random methods" raise an "anxiety" in him (8). This brief moment neatly establishes the connection between the narrator's (small, but perhaps important) desire to understand and the resulting desire to control. Rather than, for example, tracing the contours of the space bimself and in that way defusing his anxiety, the narrator's implied desire is to draw cleaner, more regular lines and in that way divide the space himself — to control it rather than observe it.

This early sign of the narrator's apparent desire to understand through control is extended and given more strongly negative affective associations through a disconcerting image which recurs throughout the text: that of a lizard trapped in a bottle. Early in the novella, when the narrator tells the story of his going into town with his mother, he mentions seeing "a saggy grey lizard bigger than my hand", inside a bottle whose neck was "coin sized" so that "not even the reptile's head could have fit through" (30). Later, after he asks Drobe about it, Drobe explains that "they put them in the bottle when they're newborn or even eggs and they put food and water in for them, and they shake it out carefully to clean out their shit, and they grow in there till they get too big to leave". He goes on to say he's seen them do it with fish, and heard of them doing it with a hare (82).

Seemingly obsessed with this image, the boy repeats and elaborates on it in a long passage which bears examining in full: 
He drew a lizard in a bottle between the stems of the wall-paper's design. He came back the next day and, beside it, he drew a cat in another bottle and a fox in a third. He drew a fish in a bottle, a crow in a bottle, a mountain lion in a big bottle. He'd never seen a mountain lion but he heard them sometimes and knew he was to be afraid of them. He imagined that deep throaty growl contained by glass, and the thought fascinated him. He drew corks tight in the bottles' necks. He cramped his drawings together to keep them a secret, and he saw that without intending it he'd drawn his bottles as if neatly lined up in some strange cupboard. So he drew a shelf beneath them, and while daylight reached them and cast across them the shadows of his own reaching hand, he put down the lines of a house around the bottles, to contain them, and he drew a house to either side. He could have filled the whole of the room, covered every wall of it in the smudged lines of rendered streets, that they could be filled in turn with women and men and children in the same lines as their city, some like small women wearing masks, some people squat as if they lived underwater. Someone there would be the keeper of that city.

He wanted his pictures to be secret so he kept that city and itemized its citizens in his head. (4243)

There is something discomforting about this: first the claustrophobia one imagines, which only worsens as the list grows to include "women and men and children", then the term "itemized" combined with the image of the bottles lined up on a shelf in a cupboard. The sense is of living people constrained within rigid categories and thus reduced to objects. The note about the mountain lion, too, suggests something of the motivation behind the narrator's action; his fear of the thing is what makes trapping it so "fascinating".

Later, the narrator receives the actual bottle containing the lizard from Samma, but by that point the bottle contains only "a scaly scrap and discoloured and broken animal bones" (108). The narrator leaves the bottle behind when he leaves with the census-taker at the end of the novella. At that point, the narrator muses that "you could put a bird's egg in there and let it grow in the glass. Drobe hadn't said if anyone had ever put a baby in a bottle and let it continue. You could. Push food in, teach it through the glass, clean it out. If you were strong enough" (135). Here, the abstract image of the person trapped in the glass has its terrible history articulated. This brings its horror closer to a reader: the detail of the glass needing to be 'cleaned out' is particularly evocative.

The novella quickly associates the connection between the desire to understand or know and the desire to control with the process of taking a census - a process which, as the title suggests, is central to the text. By doing so, the novella moves beyond a generalised critique of modernity as such and towards a specific interrogation of the role of the state in producing coherent, closed systems of knowledge. As Ruppert notes, it is through "a variety of practices 
such as censuses, surveys, birth registrations, and school attendance and tax records that governing authorities know populations and create a 'legible people"' (219), a process which allows for control. An early depiction of the census is in the census-taker's former assistant's 'catechism', which brackets the novella. It appears first in part on page 22, and then again on 139, one page before the novella's end. The catechism reads, in full:

The Hope Is So:

Count Entire Nation. Subsume Under Sets. -

Take Accounts. Keep Estimates. Realize

Interests. So

Reach Our Government's Ultimate Ends.

The phrase "subsume under sets", here, has a slightly sinister edge. The theoretical collective Endnotes describe the process of subsumption in these terms:

There is something absurd about a relation of subsumption. When the particular is subsumed under a universal, that universal presents itself as the truth of this particular; indeed it is as if this particular has become nothing other than an instantiation of the universal that subsumes it. Yet it seems that there must be something left over in this process, for the abstract universal is still just what it was at the start, while the particularity which the particular had in opposition to the universal has now been abstracted away entirely. Subsumption thus appears to involve a kind of domination or violence towards the particular.

Endnotes' depiction of subsumption here seems to aptly describe the process of census taking. This relation of subsumptive violence thus mirrors the suspicion towards bringing within the 'order of the Same' which Derrida inherits from Levinas and which the previous chapter explored through the figure of the spectre and the work of mourning.

When the census taker first meets the narrator and tells him about his job, he describes the census taking project thus:

I'm putting things in sets. My job's just to count the people who were born where I was, or whose parents or grandparents were. Then I write down what I've counted. That's my job. I started years ago, when we decided we had to take stock of things. After troubles. We needed to know where we were. Where we all were. (114) 
The reference to "troubles" here, coupled with the catechism and the desire it professes to "subsume under sets" in order to "realize interests", casts the census as a response to the desire to control. It is not purely a practice of observation - rather, its abstracting force both changes what it perceives and is done with the intent to change further.

While this desire could conceivably be thought of as benign, the novella's status as a perhaps-sequel to Iron Council and the rest of the Bas-Lag trilogy confirms that the 'ultimate ends' referred to in the catechism are specifically the suppression of rebellion. Iron Council depicts a double revolution in which the citizens of the city New Crobuzon rise up and seize much of the city, while the Iron Council, a community of (socialist) train crews, track-layers, and other workers associated with the train project who seized control of their moving workplace decades earlier, return to the city to aid them. At the end of Iron Council one of the central characters, the golemancer Judah Low, believing that the first revolution has failed and that the Iron Council is going to their deaths, freezes them in time to await the moment of successful revolution. If This Census-Taker is read as a sequel to Iron Councils this has two effects. First, it conclusively ties the purpose of the census to the desire to prevent further revolutionary uprisings. Second, it recruits the frustrated desire to see the revolution completed which a reader will have likely experienced at the conclusion of Iron Council, solidifying the negative affective associations which have been built with the census itself.

Several elements of the novella suggest that This Census-Taker is a sequel to Iron Council. First, there is a moment early on in the text in which the narrator thinks he sees "a new green, outlines of tough vegetation, neither needles nor fibrous leaves, but spines on bunched and distinct knotty skin" (43-44). Running to his mother, he tells her that he saw something, that "a tree was walking" (45). Her worried reaction tells him that the vision is plausible, and when she says as if to herself that maybe "it was someone from your father's city" (45) it becomes clear that 'walking trees' do, somewhere, exist. Much later in the novella the narrator notes that on his hill "there were none of the true succulents of the desert" that he "had once imagined walking" (77). This is a clear reference to the earlier apparently walking tree, and confirms that the 'tree' was not a tree at all, but rather a cactus. Given the mother's lack of immediate disbelief, it seems entirely plausible to conclude that it was not imagined and was in fact one of the cactaceae, anthropomorphic cacti who live in New Crobuzon and feature prominently in the first novel in the trilogy, Perdido Street Station.

At one point, Drobe tells the narrator that a statue head came "from when there was a time - where the counters come from - they were scared of all the engines and they smashed them all up." (57) Later, the narrator elaborates, saying that "before we were born, rumours of 
distant insurrection meant the ordering of destruction, the gleeful dismembering of all such geared constructed figures" (58). This is a clear reference to the destruction of the machine intelligence referred to as the 'construct council' in Perdido Street Station, which by the time of Iron Council has been discovered and eradicated by the New Crobuzon militia.

In one of the only descriptions of his former life which the boy's father offers, he tells the boy that he was once "in a war. In a city", and that that war is best characterised as "high town against low", "street against street" (75). Taken alongside the raft of hints that the father is from New Crobuzon, this seems to confirm both time and place. The war which the father describes must be the failed revolution of Iron Council.

It therefore seems entirely plausible to suggest that the "troubles" (114) which the census-taker refers to as the origin of the census are the war of "street against street" which the narrator's father refers to. If this is true, it means that the census is explicitly a response to the failed revolution of Iron Council, and arises from a desire to, presumably, forestall another. It is explicitly the action of power seeking to solidify its position as power.

By combining the negative affect associated with the census with this depiction of the census as knowledge for the purposes of control (and especially centralised control), This CensusTaker, like The Last Days of New Paris, makes the case for the work of mourning, the refusal of delineated categorisation, as a political and ethical project. However, This Census-Taker differs from The Last Days of New Paris in two critical ways. The first of these is its extension of the demand that the work of mourning be done to the text itself — a demand which it mobilises through its use of ambiguity and lack of closure. The second is the implications of haunting's decoding force for the individual subject.

This Census-Taker is a text riven by ambiguities and gaps. Some of the central questions which drive its narrative, for example, go unanswered by the text, such as most obviously the question of whether the mother, or indeed anyone, was killed in the moments before the beginning of the narrative discourse. The novella begins with its narrator running into town, scared, and shouting that "my mother killed my father!" (2), a claim which is reversed by page six, when the narrator settles on the claim that it was the father who had killed the mother. This reversal is presaged by a long introduction, describing over the course of multiple pages the boy running, panicked, down the hill. This extended build-up establishes the suspense which drives the question. A reader cannot help but wonder what it is that has provoked such an emotional state. The reversal of the narrator's claim, rather than deflating this suspense, seems to intensify it. All the tension which has been built up is not released but rather the sense of mystery is heightened. 
In his defence against the narrator's accusations, the father produces a letter purporting to be from the narrator's mother in which she seemingly states that she is leaving them and the town and returning to her former home (61). While the narrator never believes that the letter is genuine, his emotional state means that this letter is enough, perhaps, to cast his own alreadyunclear memories into doubt, raising the question for a reader of which of the two is to be trusted.

This question seems to be settled when the census-taker, having emerged from the hole in the hill where the narrator's father supposedly disposed of the narrator's mother's body, goes down the hill and returns with, presumably, the father's corpse - the implication being that he has discovered the mother's body at the bottom of the hole and killed the father in retaliation. While the census-taker has the narrator keep his eyes closed throughout the scene, the implication of his pushing a heavy object into the hole is clear. Several things complicate this reading. First, the census-taker at no point states that he found the mother's body in the hole. This is left to be inferred by his subsequent killing of the father — but the father is clearly angry, possibly angry enough to attack the census-taker, when he is last seen in the text: he's shouting incoherently. Further, the census-taker has some motivation to take the narrator as an assistant, and cannot do that without removing the father. This raises the possibility that the two may have come into conflict regardless of whether the census-taker found the mother's body in the hole.

The census-taker's motives are also called into question by the implication that he may have killed Drobe. Drobe's disappearance is another of the novella's unresolvable mysteries, but we are told that hearing Drobe's name "made the man look away from me, down the dark slope", and that "he seemed to hold his breath" (131). Given that Drobe was in contact with the census-taker's former assistant who had discovered that he was no longer acting on the orders he claimed to, and fled him with some of his papers, one might conclude that one of the distinctive gunshots which precede the census-taker's appearance in the novella was the sound of his killing Drobe. This implication casts the census-taker's trustworthiness in a particularly bad light, and more specifically suggests that he might be willing to murder the narrator's father regardless of whether he discovered evidence to justify it. For this reason, the fact of the census-taker's killing the father does not answer the question of whether the father murdered the mother. At the end of the novella, a reader is denied the ability to close off this question.

These readerly difficulties around the ability to answer questions raised by the narrative are paralleled by interpretative difficulties around symbolism and allegory. While there are images which, recurring throughout the novella, seem to gesture towards specific figurative readings (such as the recurring motif of the lizard grown in the bottle, as discussed above), others resist 
easy interpretation. One clear example of this is the hole in the hill itself, and the father's killing of animals and throwing their bodies into the hole. The narrative acts to imbue the hole and the act of killing with potential meaning. See, for example, the extraordinary description of the first time the narrator remembers seeing his father throw a corpse (in this case, that of a dog) into the hole:

My father stood at the lip. He looked down into the black for a long time then pulled his arm back and swung it forward and released the dead dog just so, so it arced up over the trash-pit hole and paused and accelerated down into it in a curve so perfect everything seemed to have led to it.

The dog was born to descend this way. Millions of years ago, the stone had split to receive it.

My father stared down into the hill with such focus it was as if he had done all of this, this killing, because he had to see an animal fall." (15-16)

The assertion that the stone had split for this purpose, especially, is highly suggestive of a figurative or allegorical reading. This effect is compounded by the repeated word "and" throughout the passage, the rhythmic recurrence of which seems to mirror the inevitability of the events described. Finally, the image of the hole reoccurs on the final page of the novella when, after leaving the town with the census-taker, the narrator wakes, murmuring that "I dreamed of the hole". The phrase repeats a few lines later:

I dreamed of the hole, I said. I remember saying it, but I don't remember the dream exactly, though all my memories before that moment and after — forever after, you might say — had and have to them a must and coldness that can only have come from inside a hill. (140)

It is almost on this image, and this strange statement about memory, that the novella ends. No symbolic meaning in particular is attached to the hole, yet the claim that "all my memories before that moment and after" are touched by its quality speaks to it having a deep importance. If the narrator has chosen that image out of all of the images available to him (the empty room, the wooded hill, his mother's bedroom) to characterise the events described in This Census-Taker that seems to imply a particular aptness. However, the novella denies its reader the possibility of easily reading the image and determining that that aptness is.

Another of these images which resist easy accounting comes when, walking back from the town at night, the narrator extrapolates from a description of his mother's former home to 
suggest that "you take apart all the buildings", "take out all the bricks and push them down and set fire to them". The narrator goes on to imagine bats "big as houses and not flying but walking in their horrid way on the tips of their wings and their claws, and the ash was baked solid so none of it gusted up at their touch". He suggests that "that was where they might live, the bats. Batland between the town and the hill, the country!" (38). This strange sequence continues with the narrator describing the destruction of the city as "how we could help" (39) - a description which he only realises he has been saying aloud when his mother interrupts him. While this sequence does have something of the free association of a child's imagination to it, it is worth considering the degree to which the setting is already the product of this kind of imagination. In fact, the burned city populated by massive bats, or the "circle of revived towerblocks around a huge field of weeds" (39) could as easily be the setting of a Miéville text. Perhaps, in that novella, a character might muse about a strange child forced to live with his father, who is a murderer, and makes magical keys. What this aesthetic similarity does is imbue the narrator's seemingly aimless musings with a demand for interpretation - a demand which their paucity of detail makes unfulfillable.

Continuing this theme of denying a reader an easy purchase on the text, This Census-Taker also includes various codes and ciphers. Early in the novella, the narrator recounts his "manager", the census-taker, telling him that he will be expected to keep three books. The first will be "a book of numbers" - the census itself (20). The third book is a book for the writer. The narrator describes his as "a notebook that fits in my hand. It's a quarter full already, with my smallest writing, using symbols for my secrets" (21). The second book is "this box of papers" (21), so that the conceit of the novella is that it is this second book which a reader is reading. That book is "for readers", it is "performance", and importantly "you can still use it to tell secrets and send messages. Even so. You could say them right out, but you can hide them in the words, too; in their letters, in the ordering on lines, the arrangements and rhythms" (21). A reader should expect, then, for there to be hidden messages in the novella itself.

One such hidden meaning is concealed fairly simply within the repeated catechism. Reading only the first letter of each word, the catechism goes from this:

The Hope Is So:

Count Entire Nation. Subsume Under Sets. -

Take Accounts. Keep Estimates. Realize

Interests. So

Reach Our Government's Ultimate Ends. 
To this:

This / Census - / Taker / Is / Rogue.

The narrator's response, "In / Keying, no obstacle withstands" (23) then becomes the straightforward response "I know". This example of a simply broken cipher has two effects. First, it confirms what the father said, that the census-takers were recalled. However, this throws little light on the census-taker himself: does he continue with his work out of a desire to subvert, somehow, the will of the state? Or does his continued obedience to its old order reflect his devotion to the state, or an attempt to assume the mantle of state power for himself? Second, the presence of the catechism cipher alerts a reader to the possibility of other ciphers' presence in the text.

One section in particular which seems likely to contain codes of this sort is the short chapter beginning on page 54. Earlier, on page 23, the narrator had noted that "my second book comes fast, the noisiest of the three. I'm not writing it with a pen. My fingers quickstep on these keys and my second book rattles out" (23). That the section on 54 involves the narrator "writing by hand now" and is not the facts and figures of the first book strongly suggests that this section is a fragment of the narrator's third book, the book in which he notes he will be "using symbols for my secrets" (21). The first sentence in the section seems as if it will bear this out: it reads “take accounts, keep estimates, realize interests" (54) - part of the catechism which makes sense read alone, but which does not decipher into anything meaningful if the same pattern as the catechism cipher is followed: it yields "takeri". One could read that as the syntactically strange "Taker I", an assertion of the status of the subject, the 'I', as "taker", but this is a stretch. In fact, none of page 54 produces meaning when subjected to the first-letter deciphering. While all the signs point to hidden codes, none are to be easily found.

Like the ambiguous central mystery and cryptic seemingly-symbolic images, the suggested presence of ciphers which a reader cannot be expected to detect and solve puts a reader in the position of needing to relate to the text without bringing it within the sphere of rationally accountable knowledge. To return to the figure of the ghost, what is demanded by This Census-Taker is that a reader be present with the ghost — be beside it — without either grasping it or banishing it. Like The Last Days of New Paris, what is being advocated for is what might be termed the work of mourning — but unlike The Last Days of New Paris, This Census-Taker demands that 'mourning' be done for the text itself. 
This shift in focus away from a depiction of the problem itself and towards an intervention, of sorts, is also evident in the novella's treatment of the subject. Where The Last Days of New Paris works to connect Thibaut's apparent betrayal of his comrades to the work of mourning, arguing for what might be termed the 'decoding' side of the appeal to social groups (that is, in favour of the dissolution of rigid social groupings rather than their maintenance), This Census-Taker extends that decoding past the question of the group and into the question of the individual, destabilising it as a rigid monadic unit.

In an article which presages Crowds and Party, 'Enclosing the Subject', Dean argues that contemporary ideology, rather than 'interpellating the individual as a subject' as the Althusserian formulation has it, "interpellates the subject as an individual" - that is, it severs them from the larger social body, it is "a coercive and unstable product of the enclosure of the common in never-ceasing efforts to repress, deny, and foreclose collective political subjectivity" (363). While Dean eventually argues for the party as "affective infrastructure" (Crowds and Party 174) which will allow this individuating force to be overcome, and that the "iron law of oligarchy" (Crowds and Party 140) makes such centralised, authoritative structures inevitable, her argument must run up against the suspicion towards rigid organisational structure which infuses The Last Days of New Paris and which is carried into This Census-Taker through its observation that it is the census itself, an operation of the state, which begins the individuating process. While Dean is no doubt correct to point to an intensification of individuation (or, to use a term from a parallel tradition, atomisation) in post-Fordist society, This Census-Taker connects individuation (via the census) to modernity as such. This seems to rule out Dean's turn to the party and the seizing of the state as an answer which might be acceptable for This Census-Taker. Instead, seemingly having accepted Dean's claims for ideology as an individuating force which fractures the collective political subject, the novella works to undermine the strict individuation which prevents the formation of the crowd. It does this through the deconstruction of individual identity.

A first sign that any straightforward conception of identity will be difficult to sustain in the novella is the lack of names given to many of the central characters. The narrator never reveals his own name, and his parents and the census-taker are all referred to specifically by their titles or roles rather than by their names, which are likewise never revealed. The narrator never capitalises 'mother' or 'father'. This suggests that the terms are being used to refer to their roles in a larger, social sense, rather than specifically in relation to the narrator. Furthermore, they are referred to differently by different people; for example, the father is called 'councilman' at one point, a title which seems very poorly fit for the key-maker living alone with his family and barely interacting with the town (47). This alerts a reader to his potentially shifting identity. While 
'he' acts as the narrator's father within the specific context of the town, that is not his identity he assumes other identities in other contexts. By not giving the father a specific name, the novella denies him any identity apart from these shifting, contextual titles — it reveals the way in which the monadic individual subject is essentially a fiction.

One of the most immediately apparent oddities of This Census-Taker is the use of pronouns, particularly in the opening scenes. The novella begins "A boy ran down a hill path screaming. The boy was I". As the description continues, the switching of pronouns occurs even within the same sentence: "He was nine years old, I think, and this was the fastest he'd ever run, and he stumbled and careered and it seemed many times as if he would fall into the rocks and gorse that surrounded the footpath, but I kept my feet and descended into the shadow of my hill" (1). These shifts in pronoun between first and third person continue throughout the novella, such that the view one gets of the narrator is seemingly both from within and from without; the narrator is both identified with the boy and not. Later, the second person is also used (109). This shifting of perspective between inside and outside the self transgresses its clearly delineated boundaries, destabilising them.

The changing of viewpoint is accompanied by shifting and ambiguous memory. This is first, and most clearly, evident in the opening scene. Having run downhill to the town, the narrator holds up hands which he "thought were bloody", and shouts that "my mother killed my father" (2). After a digression in which the narrator describes where he lives, the scene continues. The narrator is confused because the person talking to him repeats what he has claimed and he realises that "the boy, $\mathrm{I}$, had said his mother killed his father". At this stage the first suggestions that this memory is unreliable appear. The narrator recalls:

Still now if I consider the thing I saw in my house that day what comes back to me first is my mother's hands: her calm expression, the sight of her braced and striking, her hands coming down hard, a knife, my father's eyes closed, a glimpse of his mouth, his mouth full of blood, blood on the pale flowers of the walls, and the boy has to think all that first, I have no choice, I can't think around it and every time it takes me a moment to reflect and prepare to say that no, that's not what it was, surely, that the face of the person being hit was hidden, or certainly that it wasn't my father's (5).

By the next page, the narrator's story has reversed. "No", he says, "my father. Someone. My mother." (6). As it emerges, neither of those first statements were true: the narrator's hands are clean, and his father is unwounded and alive. These flaws and mistakes in memory persist throughout the text, to the point that the narrator describes "thinking" his "past self" as "mostly 
a mystery story" (88). His past self is, in his words, a "stranger child" for whom he has to "care" (104).

The narrator's shifting perspective on himself and the unreliability of his memories is accompanied by an inability to make his own choices

— not only, though most clearly, because he exists in a world in which he has a material lack of agency and relies on the support of his father, but also in the case of his own bodily autonomy. As noted in the passage above, the narrator is forced, has "no choice" (5) but to think through the imagined image of his mother killing his father before being able to speak what he now believes is the truth. His mind is, evidently, not entirely his own. This is also demonstrated when, having decided to run away from his father for a second time, the narrator descends the hill only to find that his legs stop working, seemingly of their own accord (104). The narrator initially speculates that his father's magic, linked to his making of keys, is what is preventing his escape, and concludes that this is the case (105). This conclusion, though, is undercut by two things. First, the father's magic is carefully never demonstrated to work in a supernatural sense at any point in the text. While he is often asked to accomplish certain tasks, there is never any definitive evidence that his keys do what everyone believes they do. Secondly, at the point at which he is seemingly prevented from going further, the narrator meets Samma. When she leaves, the narration shifts into an address from the present of the text's writing, and the narrator asks of his younger self "you wanted to put your foot down after her, but you didn't, maybe couldn't. You watched her go" (109). That "maybe couldn't", from the perspective of the narrator reintroduces doubt that there is any magical force preventing the narrator from leaving the hill. This denial of autonomy, then, casts the monadic individual subject into doubt by questioning one of its central traits. As Dean puts it, the subject of the crowd (and I would argue the subject of This CensusTaker) is "heterogeneous, conflictual, temporary, unbounded", standing in stark contrast to the "fantastically independent and enduring" subject of capitalist liberalism (Dean Crowds and Party 193).

For a reader who has been attentive to the demand made by the negative association between the census and control — who has been positioned to consider the work of mourning as the transgression of stable boundaries - these problems for the monadic central identity of the protagonist become challenges to their own coherent, monadic identity. This challenge, by eroding some of the boundaries which current hegemonic consensus imposes, might be read as filling the role of the party in Dean's conception, 'holding open' a gap in our setting so as to enable a desire for collectivity (20). On the other hand, the specifically cultural intervention on the behalf of collectivity against individuality does not require the formation of the party; that 
question is able to be deferred. While Dean's argument for the necessity of the party includes the claim that the crowd is "necessary but insufficient, an incomplete part of a politics not yet the politics of the part" (109), she also notes that "the crowd is not a community", that it "doesn't have a history" and "is not held together by unstated norms" (14) — a list to which one might add traditions or the bonds of fraternity. For those who find the centralising hierarchy of the party to be a source of concern as much as a source of optimism, then, the deconstruction of the autonomous subject offers a tentative first step — not a commitment to the party, but perhaps not the capitulation to late capitalism of which Dean accuses a politics of difference either.

To return to the questions with which The Last Days of New Paris left us: if we must have community without exclusion, politics without power, perhaps this is where This Census-Taker gestures: towards the formation of the crowd, with or without the party. 


\section{Conclusion:}

\section{Mourning in Practice}

This thesis began by observing two divergent strains of thinking around science fiction and fantasy fiction. One tendency in this thinking aims to discover, in fiction, information about the world we live in. This 'diagnostic' tendency is concerned with revealing, uncovering, and unmasking - with perceiving. On the other hand, there also exists a strain concerned with destabilising, complicating, and challenging the given-ness of that perception. Having pursued the encounter between these two tendencies through their initial collision in Miéville's work in The City \& the City into 2016's two considerations of political possibility in the present moment, it now seems possible to trouble and to expand on, in some small way, each of these competing strains.

To address the 'diagnostic' practise of reading, it seems worth returning briefly to the two 2016 novellas and drawing out an element of both which has so far gone unremarked: the presence within each text of its own textual (or rather metatextual) production.

Each novella features its own writing. In the case of The Last Days of New Paris, this production takes the form of the project which Sam initially, falsely, says she is working on, and which Thibaut apparently picks up after her death: the collection of photographs and descriptions which will form a volume Sam calls “The Last Days of New Paris” (39). Thibaut describes the project as "the materials of a eulogy" (55), and after Sam's death it is the continuation of this project which becomes his mission (168). The record of New Paris eventually, it is implied, (by the writer's assumption that the old man from whom he hears the story is Thibaut himself (177), an assumption which is corroborated by his having "battered, ancient, blood- and dirt- and ink-stained" notebooks (175)), becomes the novella itself. The novella thus has two existences: one outside the world of the text and written by Miéville, and the other within the world of the text as the final form of Sam's project of remembrance. Importantly, Thibaut's continuation of this project through the production of the eulogy continues even despite the fact that the "days" in question were not, in fact, the "last" — as Thibaut puts it, "The Last Days of New Paris needs writing. Even though these are not the last days, he decides" (168). The production of the eulogy in advance of or even irrespective of the 
'death' of its subject epitomises the relation of mourning. It demonstrates that what is being advanced is not a concern for the past as such — not only, as Benjamin might put it, an awareness of the ways in which the present's apparent permanence is ruptured by traces of past epochs - but rather a potential model for the production of knowledge in the present.

A metatextual model of engagement with the world also features in This Census-Taker. The element of knowledge production I have focused on in chapter three is the census itself but the census is, notably, broken into three parts, each of which is recorded in a separate book. The first book "is a book of numbers. It's lists and calculations" (21). This book forms the census as we are familiar with it: a numerical record which both records the individual as an individual and places them within a given set of taxonomic categories. The second book, though, is a record of the world in a quite different style. It is, according to the conceit of the novella, This Census-Taker itself, "this box of papers" (21). This metatextual element of the novella is easily forgotten, though the narrator does remind a reader of it occasionally (62). In an early description of the census-taker's former assistant's second book, the narrative which is being continued as This Census-Taker, the narrator describes snippets of notes and records of events (21-22). This is, recognisably, a narrative record, quite distinct from the reduction to numerical measures of the first book. Like The Last Days of New Paris, the second book might be read as an inverted reflection of its subsumptive, instrumentalising cousin, the first book of the census. In this way, two distinct types of knowledge production are figured within the novella.

Both novellas, then, posit their own existence as texts within their respective narrative worlds. These two metatextual narratives, I want to suggest, each demonstrate the work of mourning in practise. Rather than stressing the penetrating gaze of the scientist or detective, these narrative texts (much like Borlú's practise of detection in The City \& the City, though far further developed) work to move the human from the category of the object into the category of the infinite. They stress openness, even vulnerability, in the face of the encounter.

Importantly, for our work here, they also trouble a critical practise of reading which is concerned with uncovering the truth. More than challenging the 'given-ness' of the 'perceptible world of literal facts', as Vint suggests, they challenge it on ethical grounds (Vint "Ab-realism" 40). More than suggesting that such a world is limited by perception, the inclusion of narratives of the encounter in the two novellas is linked to both the criticisms of modernity levelled by Romanticism and to the ossification and inflexibility of coherent organisational structures. The desire to uncover and perceive the truth, the metanarratives suggest, might be a part of the very thing which traps us in the iron cage. This is, of course, not to suggest that engagement with the world of perceptible facts is to be avoided, but simply to note that the line of thinking which I 
have pursued through Miéville's work here is as interested, if not more interested, in troubling perception as in perceiving.

The work of mourning also, I hope, has the effect of extending or troubling the second of our tendencies in thinking around science fiction and fantasy. It would be tempting to, following Miéville's closing words in October, suggest that it is an awareness of "the switches onto hidden tracks through wilder history" (32) as such, of alternative possibilities as alternative possibilities which the attempt to imagine other worlds generates.

What I hope to have demonstrated here is that the encounter with radical difference is not limited to this rather forlorn hope - that Miéville's destabilising of the given-ness and seeming inevitability of the present state of things does not only register an openness towards the future. Rather, it places that openness at the heart of what a utopian future should be. 


\section{Works Cited}

Althusser, Louis. For Marx. Verso, 1969.

Ansible 168, July 2001. https://news.ansible.uk/a168.html. Accessed 25 Feb. 2018.

Bauman, Zygmunt, and Carlo Bordoni. State of Crisis. Wiley, 2014.

Bloch, Ernst. Heritage of Our Times. Wiley, 2009.

Bould, Mark, and China Miéville, editors. Red Planets Marxism and Science Fiction. Wesleyan, 2009.

Brown, Gareth. 'In Iron Light: Eeriness, Decomposition and Social Movements'. Culture and Organization, 2016, pp. 1-18.

Chu, Seo-Young. Do Metaphors Dream of Literal Sleep? Harvard University Press, 2010.

Critchley, Simon. Ethics-Politics-Subjectivity: Essays on Derrida, Levinas and Contemporary French Thought. Verso, 2009.

Dean, Jodi. Crowds and Party. Verso, 2016.

---. Democracy and Other Neoliberal Fantasies: Communicative Capitalism and Left Politics. Duke University Press, 2009.

---. The Communist Horizon. Verso Books, 2012.

Delany, Samuel R. Return to Nevèrÿon: The Complete Series. Open Road Media Sci-Fi \& Fantasy, 2017. 
Deleuze, Gilles. Anti-Oedipus: Capitalism and Schirophrenia. Penguin, 2009.

Derrida, Jacques. Politics of Friendship. Verso, 2005.

---. Specters of Marx: The State of the Debt, the Work of Mourning and the New International. Routledge, 2006.

Eley, Geoff. 'Fascism Then and Now'. Socialist Register, vol. 52, no. 52, Sept. 2015.

El-Ojeili, Chamsy. 'Post-Marxist Trajectories: Diagnosis, Criticism, Utopia'.

Sociological Inquiry, vol. 80, no. 2, 2010, pp. 261-282.

Endnotes. The History of Subsumption.

https://endnotes.org.uk/issues/2/en/endnotes-the-history-of-subsumption. Accessed 5 Dec. 2017.

Fisher, Mark, and Jeremy Gilbert. 'Capitalist Realism and Neoliberal Hegemony: A Dialogue'. New Formations, no. 80/81, 2013, p. 89-101.

Freedman, Carl. 'A Note on Marxism and Fantasy'. Historical Materialism, vol. 10, no. 4, Dec. 2002, pp. 261-71.

Freedman, Carl Howard. Art and Idea in the Novels of China Miéville. Gylphi, 2015.

---. Critical Theory and Science Fiction. Wesleyan University Press : University Press of New England, 2000.

Frow, John. Genre. Routledge, 2005.

Gilbert, Jeremy. Anticapitalism and Culture: Radical Theory and Popular Politics. Bloomsbury Publishing, 2008.

Hanna, Barbara Elizabeth, and Peter Cowley. 'Breach of Contact: An Intercultural 
Reading of China Miéville's “The City and The City". PORTAL Journal of Multidisciplinary International Studies, vol. 11, no. 2, Aug. 2014.

Hühn, Peter. 'The Detective as Reader: Narrativity and Reading Concepts in Detective Fiction'. MFS Modern Fiction Studies, vol. 3, no. 3, 1987, pp. 451-466.

Jameson, Fredric. Archaeologies of the Future: The Desire Called Utopia and Other Science Fictions. Verso, 2005.

---. 'Radical Fantasy'. Historical Materialism, vol. 10, no. 4, Dec. 2002, pp. 273-80.

'Letters: Left Unity Ready to Offer an Alternative'. The Guardian, 12 Aug. 2013, http://www.theguardian.com/politics/2013/aug/12/left-unity-alternative.

Löwy, Michael. 'Marx’s Dialectic of Progress: Closed or Open?' Socialism and Democracy, vol. 14, no. 1, Jan. 2000, pp. 35-44.

---. Morning Star: Surrealism, Marxism, Anarchism, Situationism, Utopia. University of Texas Press, 2009.

Löwy, Michael, and Robert Sayre. Romanticism Against the Tide of Modernity. Duke University Press, 2001.

Lukács, Georg. The Historical Novel. Merlin Press, 1965.

March-Russell, Paul. 'Signatures of the Invisible: Reading Between The City \& The City and Christopher Priest's The Glamour'. China Miéville: Critical Essays, Gylphi Limited, 2015.

Marx, Karl, and Friedrich Engels. The German Ideology. International Publishers Co, 1970.

McNeill, Dougal. 'Failing Better: Iron Council, Benjamin, Revolution'. China Miéville: Critical Essays, Gylphi Limited, 2015. 
Miéville, China. Between Equal Rights: A Marxist Theory Of International Law. Brill, 2005.

---. 'Cognition as Ideology: A Dialectic of SF Theory'. Red Planets: Marxism and Science Fiction. 2009.

---. 'Editorial Introduction'. Historical Materialism, vol. 10, no. 4, Dec. 2002, pp. 3949.

---. Embassytown. Random House Publishing Group, 2011.

---. Iron Council. Del Rey/Ballantine Books, 2004.

---. King Rat. Tom Doherty Associates, 2000.

---. Kraken. Random House Publishing Group, 2010.

---. 'M.R. James and the Quantum Vampire'. Weird Fiction Review, 29 Nov. 2011.

---. October: The Story of the Russian Revolution. Verso Books, 2017.

---. Perdido Street Station. Random House Publishing Group, 2003.

---. Railsea. Pan Macmillan, 2012.

---. The City \& The City. Random House Publishing Group, 2009.

---. The Last Days of New Paris. Random House Publishing Group, 2016.

---. The Scar. Ballantine Books, 2004.

---. This Census-Taker: A Novella. Random House Publishing Group, 2016.

---. Un Lun Dun. Tor UK, 2007. 
Monleón, José B. A Specter Is Haunting Europe: A Sociobistorical Approach to the Fantastic. Princeton University Press, 1990.

Mosse, George L. The Crisis of German Ideology; Intellectual Origins of the Third Reich. Grosset \& Dunlap, 1964.

Not a Coup But a Blaze | Salvage. http://salvage.zone/online-exclusive/not-a-coup-but-a-blaze/ Accessed 19 Nov. 2017.

Pensky, Max. Method and Time: Benjamin's Dialectical Images. Cambridge University Press, 2004.

Polanyi, Karl. The Great Transformation: The Political and Economic Origins of Our Time. Beacon Press, 2001.

Rabinbach, Anson. 'Unclaimed Heritage: Ernst Bloch's Heritage of Our Times and the Theory of Fascism'. New German Critique, vol. 11, 1977, pp. 5-21.

Rankin, Ian. Hide and Seek. St. Martin's Press, 1997.

Rankin, Sandy. 'AGASH AGASP AGAPE: The Weaver as Immanent Utopian Impulse in China Miéville's Perdido Street Station and Iron Council'. Extrapolation, vol. 50, no. 2, Summer 2009, p. 239-257.

Ruppert, Evelyn. 'Population Objects: Interpassive Subjects'. Sociology, vol. 45, no. 2, Apr. 2011, pp. 218-33.

Salvage Perspectives \#1: Amid This Stony Rubbish | Salvage.

http://salvage.zone/inprint/salvage-perspectives-1-amid-this-stony-rubbish/. Accessed 29 Jan. 2018. 
Salvage Perspectives \#2: Awaiting the Furies | Salvage.

http://salvage.zone/inprint/salvage-perspectives-2-awaiting-the-furies/

Accessed 29 Jan. 2018.

Salvage Perspectives \#4: Order Prevails in Washington | Salvage.

http://salvage.zone/in-print/order-prevails-in-washingston/.

Accessed 29 Jan. 2018.

Scott, James C. Seeing Like a State: How Certain Schemes to Improve the Human Condition Have Failed. Yale University Press, 1998.

Segal, Eyal. 'Closure in Detective Fiction'. Poetics Today, vol. 31, no. 2, June 2010, pp. $153-215$.

Sontag, Susan. Under the Sign of Saturn. Vintage Books, 1981.

Tolkien, J. R. R. The Lord of the Rings. Houghton Mifflin Company Trade \& Reference Division, 2001.

Tormey, Simon, and Jules Townshend. Key Thinkers from Critical Theory to Post Marxism. Sage Publications, 2006.

Toscano, Alberto. 'The Open Secret of Real Abstraction'. Retbinking Marxism, vol. 20, no. 2, 2008, pp. 273-287.

Traverso, Enzo. Left-Wing Melancholia: Marxism, History, and Memory. Columbia University Press, 2016.

Vint, Sherryl. 'Ab-realism: Fractal Language and Social Change'. China Miéville: Critical Essays, Gylphi Limited, 2015.

---. 'Introduction: Special Issue on China Miéville'. Extrapolation, vol. 50, no. 2, Jan. 2009, pp. 197-99. 
---. 'Possible Fictions: Blochian Hope in The Scar'. Extrapolation, vol. 50, no. 2, Summer 2009, p. 276-292.

Watermelon, Daphne. Resigning from the Socialist Workers Party.

http://internationalsocialismuk.blogspot.com/2013/03/fao-central-committee-ofsocialist.html. Accessed 25 Feb. 2018.

Žižek, Slavoj. In Defense of Lost Causes. Verso, 2008. 